NBER WORKING PAPER SERIES

\title{
INTERNATIONAL MIGRATION, REMITTANCES, AND HOUSEHOLD INVESTMENT: EVIDENCE FROM PHILIPPINE MIGRANTS' EXCHANGE RATE SHOCKS
}

\author{
Dean Yang \\ Working Paper 12325 \\ http://www.nber.org/papers/w12325 \\ NATIONAL BUREAU OF ECONOMIC RESEARCH \\ 1050 Massachusetts Avenue \\ Cambridge, MA 02138 \\ June 2006
}

Email: deanyang@umich.edu. Address: 440 Lorch Hall, 611 Tappan Street, University of Michigan, Ann Arbor, MI 48109. A previous version of this paper was circulated under the title "International Migration, Human Capital, and Entrepreneurship." I have valued feedback from Kerwin Charles, Jishnu Das, John DiNardo, Hai-Anh Dang, Quy-Toan Do, Eric Edmonds, Caroline Hoxby, Larry Katz, Michael Kremer, Sharon Maccini, Justin McCrary, David Mckenzie, Ted Miguel, Ben Olken, Caglar Ozden, Dani Rodrik, and Maurice Schiff; participants in seminars at UC Berkeley, Stanford University, University of Western Ontario, Columbia University, the World Bank, and the Federal Reserve Bank of New York; audience members at the Minnesota International Economic Development Conference 2004 and the WDI/CEPR Conference on Transition Economics 2004 (Hanoi, Vietnam); and two anonymous referees. HwaJung Choi provided excellent research assistance. I am grateful for the support of the University of Michigan's Rackham Junior Faculty Fellowship, and the World Bank's International Migration and Development Research Program. The views expressed herein are those of the author(s) and do not necessarily reflect the views of the National Bureau of Economic Research.

(C2006 by Dean Yang. All rights reserved. Short sections of text, not to exceed two paragraphs, may be quoted without explicit permission provided that full credit, including $\odot$ notice, is given to the source. 
International Migration, Remittances, and Household Investment: Evidence from Philippine Migrants' Exchange Rate Shocks

Dean Yang

NBER Working Paper No. 12325

June 2006

JEL No. D13, F22, I2, J22, J23, J24, O12, O15

\begin{abstract}
$\underline{\text { ABSTRACT }}$
Millions of households in developing countries receive financial support from family members working overseas. How do migrant earnings affect origin-household investments? This paper examines Philippine households' responses to overseas members' economic shocks. Overseas Filipinos work in dozens of foreign countries, which experienced sudden (and heterogeneous) changes in exchange rates due to the 1997 Asian financial crisis. Appreciation of a migrant's currency against the Philippine peso leads to increases in household remittances received from overseas. The estimated elasticity of Philippine-peso remittances with respect to the Philippine/foreign exchange rate is 0.60 . These positive income shocks lead to enhanced human capital accumulation and entrepreneurship in migrants' origin households. Child schooling and educational expenditure rise, while child labor falls. In the area of entrepreneurship, households raise hours worked in self-employment, and become more likely to start relatively capital-intensive household enterprises.
\end{abstract}

Dean Yang

Gerald R. Ford School of Public Policy

Department of Economics

University of Michigan

440 Lorch Hall

611 Tappan Street

Ann Arbor, MI 48109

and NBER

deanyang@umich.edu 


\section{Introduction}

Between 1965 and 2000, individuals living outside their countries of birth grew from $2.2 \%$ to $2.9 \%$ of world population, reaching a total of 175 million people in the latter year. ${ }^{1}$ The remittances that these migrants send to origin countries are an important but relatively poorly understood type of international financial flow. In 2002, remittance receipts of developing countries amounted to US $\$ 79$ billion. ${ }^{2}$ This figure exceeded total official development aid (US\$51 billion), and amounted to roughly four-tenths of foreign direct investment inflows (US\$189 billion) received by developing countries in that year. ${ }^{3}$ While the figures for official development aid and FDI are likely to be accurate, by most accounts (for example, Ratha (2003)) national statistics on remittance receipts are considerably underreported. The remittance figure may therefore be taken as a lower bound. An understanding of how these migrant and remittance flows affect migrants' origin households is a core element in any assessment of how international migration affects origin countries, ${ }^{4}$ and in weighing the benefits to origin countries of developed-country policies liberalizing inward migration (as proposed in Birdsall, Rodrik, and Subramanian (2005) and Bhagwati (2003), for example).

What effects do migrant earnings have on migrants' origin households - in particular, on investments in human capital and productive enterprises? An important body of research in economics examines the multiple roles migration can play for households in developing countries (Lucas and Stark (1985), Rosenzweig and Stark (1989), Stark (1991), and Poirine (1997), among others; see also Taylor and Martin (2001) for an overview). Accumulated migrant earnings can allow investments that would not have otherwise been made due to credit constraints and large up-front costs. Many studies find migration and remittance receipts to be positively correlated with various types of household investments in developing countries. ${ }^{5}$ By contrast, others argue that resources received from overseas rarely fund productive investments, and mainly allow higher

\footnotetext{
${ }^{1}$ Estimates of the number of individuals living outside their countries of birth are from United Nations (2002), while data on world population are from U.S. Bureau of the Census (2002).

${ }^{2}$ The remittance figure is the sum of the "workers' remittances", "compensation of employees", and "migrants' transfers" items in the IMF's International Financial Statistics database for all countries not listed as "high income" in the World Bank's country groupings.

${ }^{3}$ Aid and FDI figures are from World Bank (2004).

${ }^{4}$ Borjas (1999) argues that the investigation of benefits accruing to migrants' source countries is an important and virtually unexplored area in research on migration.

${ }^{5}$ For example: Brown (1994), Massey and Parrado (1998), McCormick and Wahba (2001), Dustmann and Kirchkamp (2002), Woodruff and Zenteno (2003), and Mesnard (2004) on entrepreneurship and small business investment in a variety of countries; Adams (1998) on agricultural land in Pakistan; Cox-Edwards and Ureta (2003) on child schooling in El Salvador; Taylor, Rozelle, and de Brauw (2003) on agricultural investment in China; and others.
} 
consumption. $^{6}$

A central methodological concern with existing work on this topic is that migrant earnings are in general not randomly allocated across households, so that any observed relationship between migration or remittances and household outcomes may simply reflect the influence of unobserved third factors. For example, more ambitious households could have more migrants and receive larger remittances, and also have higher investment levels. Alternately, households that recently experienced an adverse shock to existing investments (say, the failure of a small business) might send members overseas to make up lost income, so that migration and remittances would be negatively correlated with household investment activity.

An experimental approach to establishing the impact of migrant economic opportunities on household outcomes could start by identifying a set of households that already had one or more members working overseas, assigning each migrant a randomly-sized economic shock, and then examining the relationship between changes in household outcomes and the size of the shock dealt to the household's migrants.

This paper takes advantage of a real-world situation akin to the experiment just described. A non-negligible fraction of households in the Philippines have one or more members working overseas at any one time. (The figure was 6\% in June 1997 in the dataset used in this paper.) These overseas Filipinos work in dozens of foreign countries, many of which experienced sudden changes in exchange rates due to the 1997 Asian financial crisis. Crucially for the analysis, the changes were unexpected and varied in magnitude across overseas Filipinos' locations. At the same time, the Philippine peso also depreciated substantially.

The net result was large variation in the size of the exchange rate shock experienced by migrants across source households. Between the year ending July 1997 and the year ending October 1998, the US dollar and currencies in the main Middle Eastern destinations of Filipino workers rose $50 \%$ in value against the Philippine peso. Over the same time period, by contrast, the currencies of Taiwan, Singapore, and Japan rose by only $26 \%, 29 \%$, and $32 \%$, while those of Malaysia and Korea actually fell slightly (by $1 \%$ and $4 \%$, respectively) against the peso. ${ }^{7}$

Taking advantage of this variation in the size of migrant exchange rate shocks, I examine their impact on changes in household outcomes in migrants' origin households, using detailed panel household survey data from before and after the Asian financial crisis. The focus on changes in

\footnotetext{
${ }^{6}$ For example, Lipton (1980), Reichert (1981), Grindle (1988), Massey et al. (1987), Ahlburg (1991), Brown and Ahlburg (1999), and references cited in Durand et al (1996).

${ }^{7} \mathrm{I}$ describe the exchange rate shock variable in section 3.2 below.
} 
household outcomes (rather than levels) is crucial, so that estimates are purged of any association between the exchange rate shocks and time-invariant household characteristics.

Appreciation of a migrant's currency against the Philippine peso was a positive income shock for the migrant's origin household in the Philippines, and is (partly) reflected in changes in household remittance receipts from overseas. The greater the appreciation of a migrant's currency against the Philippine peso, the larger the increase in household remittance receipts (in pesos). Figure 1 displays the bivariate relationship between the percentage change in the exchange rate (Philippine pesos per unit of foreign currency) and the percentage change in mean remittance receipts for households with migrants in the top 20 destinations of Philippine overseas workers. The datapoints exhibit an obvious positive relationship. Regression analysis using householdlevel data implies an elasticity of Philippine-peso remittances with respect to the exchange rate of 0.60 - a $10 \%$ increase in Philippine pesos per unit of foreign currency increases peso remittances by $6 \% .^{8}$

These exogenous increases in migrant resources are used primarily for investment in origin households, rather than for current consumption. Households experiencing more favorable exchange rate shocks raise their non-consumption disbursements in several areas likely to be investment-related (in particular in educational expenditures), and show enhanced human capital accumulation and entrepreneurship. Child schooling and educational expenditure rise, while child labor falls. In the area of entrepreneurship, households raise hours worked in self-employment, and become more likely to start relatively capital-intensive household enterprises (transportation/communication services and manufacturing). By contrast, there is no large or statistically significant effect of the exchange rate shocks on current household consumption.

A crucial question is whether the relationship between the exchange rate shocks and household investment reflects the causal impact of the shocks. The main concern is that migrants were not randomly assigned to overseas locations, and that households whose migrants experienced better shocks might have experienced differential increases in household investment even in the absence of the shock. Such differential changes might be due to differential ongoing trends, or to correlation between the migrant exchange rate shocks and other types of household shocks (such as downturns in particular regions of the Philippines that happen to send migrants to

\footnotetext{
${ }^{8}$ As I discuss below in subsection 3.2, the total change in household income due to the exchange rate shock is only partly reflected in the observed change in remittances. The survey instruments used do not collect other information needed to quantify the total change in household income, such as overseas wages and the amount of savings held overseas. Thus the focus in this paper is simply on the reduced-form impact of the exchange rate shocks.
} 
particular countries). While such concerns are difficult to rule out completely, I address this issue in two ways. First, I gauge the stability of the regression results to accounting for changes in outcomes that are correlated with a comprehensive set of households' pre-shock characteristics. The estimated impact of the exchange rate shock is little changed (and often becomes larger in magnitude) when pre-shock household characteristics are included in regressions, providing no reason to question the causal interpretation of the results. Second, for a subset of outcomes it is possible to examine the relationship between future exchange rate shocks and changes in outcome variables prior to the crisis. This false experiment fails to reject the null that pre-existing changes in outcome variables are unrelated to future exchange rate shocks.

The shocks are most plausibly interpreted as transitory income shocks, as the vast majority of migrants are explicitly reported to be temporary migrants: their eventual return to the Philippines automatically puts an end to the period of foreign currency earnings. ${ }^{9}$ I also argue that the household investment responses do not appear to be due to changes in the likelihood of migrant returns, since controlling for migrant returns has essentially no impact on the estimates. Finally, there is little indication that real economic shocks in overseas countries correlated with the exchange rate shocks are driving the results, as measures of real economic shocks in migrants' overseas locations do very poorly in explaining changes in household outcomes, compared to the exchange rate.

This paper also contributes more broadly to understanding how households in developing countries respond to unexpected, transitory changes in economic conditions. In focusing on a household-level shock, this paper is reminiscent of studies of the impact of household-level events such as crop loss (Beegle, Dehejia, and Gatti (forthcoming)) or job loss (Duryea, Lam, and Levison (2003)) on child labor. The main distinguishing features of this study are, first, its use of a novel source of income variation (migrants' exchange rate shocks), and, second, its examination of entrepreneurial activity alongside human capital investment outcomes. ${ }^{10} \mathrm{I}$ am aware of no other study that examines the impact of exogenous income shocks on the entrepreneurial activities of developing-country households.

The remainder of this paper is organized as follows. Section 2 provides a brief discussion of

\footnotetext{
${ }^{9}$ In other words, even if the exchange rate changes persist, household income (denominated in Philippine pesos) ceases to depend on the exchange rate in the migrant's overseas location once the migrant returns home.

${ }^{10}$ Other studies of the impact of shocks on households differ in more substantial ways. Numerous studies examine the impact of locality-level shocks, such as weather shocks (Jacoby and Skoufias (1997), Jensen (2000), Rose (1999), Miguel (2005)) and heterogeneity in the local impact of the 1997 Asian crisis in Indonesia (Frankenberg, Smith, and Thomas (2003)). In such analyses, at least part of the effects found may be due to changes in locality-level economic conditions (such as wage rates), rather than merely due to changes in household income.
} 
the theoretical impact of income shocks on household investment activity. Section 3 describes the dispersion of Filipino household members overseas, and discusses the nature of the exchange rate shocks. Section 4 presents empirical results, and conducts a number of auxiliary analyses to clarify the interpretation of the results. Section 5 concludes. The Empirical Appendix presents the false experiment, and the Data Appendix describes the household surveys used and procedures followed for creating the sample for empirical analysis.

\section{Income shocks and household investments in theory}

In theory, how should transitory income shocks (such as migrants' exchange rate movements) affect household investments in child human capital and in household enterprises? If households have complete access to credit, transitory shocks should have no effect on such investments, as borrowing allows households to separate the timing of investment from the timing of income. ${ }^{11}$ But when household investments require fixed costs be paid in advance of the investment returns, and when households face credit constraints, the timing of household investments may depend on current income realizations. In particular, households may raise investments when experiencing positive income shocks.

A large body of theoretical work in economics makes predictions of this sort for households in developing-country (and, more generally, liquidity-constrained) environments. Economic models of child labor, such as Baland and Robinson (2000) or Basu and Van (1998), consider unitary households deciding on the amount of child labor in some initial period of life. Keeping children in school (and out of the labor force) leads children to have higher future wages, but such investments reduce current household income. When an absence of credit markets prevents households from shifting consumption from later to earlier periods via borrowing, keeping children out of the labor force (and in school) in initial periods can come at too high a utility cost from foregone consumption, and so it can be optimal for households to have children work. Temporary increases in household income in initial periods, then, can allow households to reduce child labor force participation and raise child schooling. The effect of such positive income shocks on child schooling is magnified if schooling involves large fixed costs, such as tuition.

\footnotetext{
${ }^{11}$ However, if the shocks are large enough to materially affect permanent or lifetime income, income effects might lead households to change their investment behavior even when there are perfect credit markets. For example, child human capital may be a normal good for households, as in Becker (1965). Small business ownership may also be a normal good; the evidence provided by Hurst and Lusardi (2004) among U.S. households may be interpreted in this light.
} 
Transitory income shocks can also affect household participation in entrepreneurial activities, if such activities are capital-intensive. When credit and formal savings mechanisms are poor or nonexistent, productive assets may play dual roles as savings mechanisms and as income sources. When households face positive income shocks, they may accumulate productive assets, and they may sell these same assets when they experience negative shocks. Of course, such accumulation and decumulation of productive assets comes at a cost in terms of maximizing income from household enterprises, but such behavior may be optimal for risk-averse households when other savings vehicles are absent. Rosenzweig and Wolpin (1993) is the canonical investigation of such behavior, in the context of rural Indian households who use bullocks (draft oxen) in this manner.

The empirical analysis to follow will examine the extent to which household investments in child human capital and entrepreneurial activity respond to unexpected migrant exchange rate shocks. Additional evidence will suggest that the exchange rate movements should largely be thought of as transitory rather than permanent shocks to household income, and that the exchange rate shocks are unlikely to be operating via channels other than household income.

\section{Overseas Filipinos: characteristics and exposure to shocks}

\subsection{Characteristics of overseas Filipinos}

Data on overseas Filipinos are collected in the Survey on Overseas Filipinos (SOF), conducted in October of each year by the National Statistics Office of the Philippines. The SOF asks a nationally-representative sample of households in the Philippines about members of the household who left for overseas within the last five years.

Table 1 displays the distribution of household members working overseas by country in June 1997, immediately prior to the Asian financial crisis. ${ }^{12}$ Filipino workers are remarkably dispersed worldwide. Saudi Arabia is the largest single destination, with $28.4 \%$ of the total, and Hong Kong comes in second with 11.5\%. But no other destination accounts for more than $10 \%$ of the total. The only other countries accounting for $6 \%$ or more are Taiwan, Japan, Singapore, and the United States. The top 20 destinations listed in the table account for $91.9 \%$ of overseas Filipino workers; the remaining $8.1 \%$ are distributed among 38 other identified countries or have an unspecified location.

\footnotetext{
${ }^{12}$ For $90 \%$ of individuals in the SOF, their location overseas in that month is reported explicitly. For the remainder, a few reasonable assumptions must be made to determine their June 1997 location. See the Appendix for the procedure used to determine the locations of overseas Filipinos in the SOF.
} 
Table 2 displays summary statistics on the characteristics of overseas Filipino workers in the same survey. 1,832 individuals were overseas in June 1997 in the households included in the empirical analysis (see the Data Appendix for details on the construction of the household sample). The overseas workers have a mean age of 34.5 years. $38 \%$ are single, and $53 \%$ are male. 'Production and related workers' and 'domestic servants' are the two largest occupational categories, each accounting for $31 \%$ of the total.

Overseas Filipinos are highly educated: $31 \%$ of overseas workers in the sample have "some college" as their highest level of education, and a further 30\% have a college degree. By comparison, among 25-44-year-olds in the general Filipino population, only $17 \%$ received some college education, while $15 \%$ have completed a college degree. The relatively high level of education among Filipino migrants is reminiscent of the findings of Chiquiar and Hanson (2005) on positive selection among Mexican migrants in the United States. ${ }^{13}$

In terms of position in the household, the most common categories are male heads of household and daughters of the head, each accounting for $28 \%$ of overseas workers; sons of head account for $15 \%$, female heads or spouses of heads $12 \%$, and other relations $16 \%$ of overseas workers. As of June 1997, the bulk of overseas workers had been away for relatively short periods: 30\% had been overseas for just 0-11 months, $24 \%$ for $12-23$ months, and $16 \%$ for $24-35$ months, $15 \%$ for 36-47 months, and $16 \%$ for 48 months or more.

\subsection{Shocks generated by the Asian financial crisis}

The geographic dispersion of overseas Filipinos meant that there was considerable variety in the shocks they experienced in the wake of the Asian financial crisis, starting in July 1997. The devaluation of the Thai baht in that month set off a wave of speculative attacks on national currencies, primarily (but not exclusively) in East and Southeast Asia. Crucially for the analysis in this paper, the crisis was quite unexpected by market participants and analysts. Radelet and Sachs (1998) provide dramatic evidence that rating agencies, independent risk analysts, investment banks, and the International Monetary Fund failed to anticipate the crisis, as public pronouncements and forecasts made no indication of increased risk through mid-1997.

Figure 2 displays monthly exchange rates for selected major locations of overseas Filipinos (expressed in Philippine pesos per unit of foreign currency, normalized to 1 in July 1996). ${ }^{14}$ The sharp trend shift for nearly all countries after July 1997 is the most striking feature of this graph.

\footnotetext{
${ }^{13}$ But see Ibarraran and Lubotsky (2005) for a contrary view.

${ }^{14}$ The exchange rates are as of the end of each month, and were obtained from Bloomberg L.P.
} 
An increase in a particular country's exchange rate should be considered a favorable shock to an overseas household member in that country: each unit of foreign currency earned would be convertible to more Philippine pesos once remitted.

I argue that a favorable migrant exchange rate movement is most appropriately interpreted as a transitory, positive income shock for the migrant's origin household in the Philippines. Most obviously, improvements in exchange rates raise the Philippine peso value of current overseas earnings, and of future earnings that the migrant expects for the remainder of the overseas stay. In addition, exchange rate improvements raise the Philippine peso value of accumulated migrant savings held in the currency of the overseas location.

The improvement in the Philippine-peso value of overseas earnings and savings might be expected to lead to higher remittances (and the empirical analysis will show this). That said, there is no reason to expect that the entire change in household income and savings due to the exchange rate shock will appear as higher remittances sent home by migrants. Migrants can continue to hold their savings overseas. What's more, some fraction of the change in household income is accounted for by future wages yet to be earned overseas in the appreciated currency. Therefore, any observed change in remittances will (perhaps substantially) understate the change in total household income associated with exchange rate movements.

Unfortunately, overseas savings and overseas wages are not reported in the Philippine household dataset used in this paper. Due to the absence of complete data on the change in household income (and of any realistic way to estimate it), I do not attempt to use the exchange rate shock as an instrumental variable for the household income shock; rather, I focus solely on the reduced-form impact of the shock.

Why are the exchange rate shocks most plausibly interpreted as transitory (as opposed to permanent) shocks to household income? First of all, while the post-crisis exchange rate changes have been quite persistent through the present day, it is not clear that migrants would have expected this to be the case. They may indeed have placed some positive probability that exchange rates would have returned to previous levels.

Second, it is reasonable to expect that the vast majority of migrants included in the dataset will eventually return to the Philippines, ending the period of foreign-currency earnings and thus making the exchange rate shock transitory in practice in its effect on household income. The great majority of migrants (95.6\%) are explicitly reported in the survey as being some category of temporary overseas worker, while only $2.8 \%$ are reported to be "immigrants". ${ }^{15}$ In

\footnotetext{
${ }^{15}$ These data refer to the question in the SOF on "reason for migration". The remaining categories are "tourist",
} 
the cross-section, most migrants are reported to have been away for relatively short periods: 84 percent of migrants were reported to have been away for less than 48 months as of mid-1997 (see Table 2). ${ }^{16}$ Migrants' temporary labor contracts typically stipulate that they must return to the Philippines upon completion of their work abroad. Although some migrants do illegally overstay their contracts, a substantial fraction of migrants are located in places where permanent migration is unlikely to be seen as attactive due to cultural distance (more than a third of migrants go to the Middle East, for example), and many have left spouses and children behind (Table 2 indicates that $40 \%$ of migrants are either heads of household or spouses of heads). Thus, the bulk of Philippine labor migrants are likely to see their overseas stays as temporary periods, during which they accumulate savings and eventually return home. ${ }^{17}$ While the empirical analysis does show that migrants extend their overseas stays somewhat in response to favorable exchange rate shocks, the magnitude of this effect is not large enough to alter the point that overseas stays are finite for the vast majority of migrants. Moreover, re-estimating the effect of the exchange rate on the child human capital and on entrepreneurial outcomes in a sample that excludes households whose migrants are reported to be immigrants yields estimates essentially identical to those reported in the main results tables. (Results available from author upon request.)

In the empirical section, I will also provide evidence that the changes in household investment do not appear to be due to a non-income channel, the change in the likelihood of migrant returns. In addition, I provide evidence that the impact on household investment does not appear to be due to real economic shocks (such as job terminations) that might have been correlated with the exchange rate shocks. ${ }^{18}$

${ }^{16}$ This is not because overseas labor migration is a recent phenomenon, so that there has not been enough time for migrants to accumulate time overseas. On the contrary, overseas labor migration from the Philippines has been substantial since the 1970s (see Cariño (1998)).

${ }^{17}$ Yang (forthcoming) provides a more detailed treatment of the interrelationships among migrants' savings, investment, and return decisions.

${ }^{18}$ This last point is not necessary for arguing that the exchange rate shocks are correctly interpreted as income shocks, as a real economic shock such as a job termination is also an income shock. However, ruling out the impact of correlated real economic shocks is useful if this paper is to shed light more broadly on the likely impact of exchange rate fluctuations on the families of migrants.
} 


\subsection{The exchange rate shock measure}

For each country $j$, I construct the following measure of the exchange rate change between the year preceding July 1997 and the year preceding October 1998:

$$
E R C H A N G E_{j}=\frac{\text { Average country } j \text { exchange rate from Oct. } 1997 \text { to Sep. } 1998}{\text { Average country } j \text { exchange rate from Jul. } 1996 \text { to Jun. } 1997}-1 .
$$

A $50 \%$ improvement would be expressed as 0.5, a 50\% decline as -0.5. Exchange rate changes for the 20 major destinations of Filipino workers are listed in the third column of Table 1. The changes for the major Middle Eastern destinations and the United States were all at least 0.50. By contrast, the exchange rate shocks for Taiwan, Singapore, and Japan were 0.26, 0.29, and 0.32 , while for Malaysia and Korea they were actually negative: -0.01 and -0.04 , respectively. Workers in Indonesia experienced the worst exchange rate change (-0.54), while those in Libya experienced the most favorable change (0.57) (not shown in table).

I construct a household-level exchange rate shock variable as follows. Let the countries in the world where overseas Filipinos work be indexed by $j \in\{1,2, \ldots, J\}$. Let $n_{i j}$ indicate the number of overseas workers a household $i$ has in a particular country $j$ in June 1997 (so that $\sum_{j=1}^{J} n_{i j}$ is its total number of household workers overseas in that month). The exchange rate shock measure for household $i$ is:

$$
E R S H O C K_{i}=\frac{\sum_{j=1}^{J} n_{i j} E R C H A N G E_{j}}{\sum_{j=1}^{J} n_{i j}}
$$

In other words, for a household with just one worker overseas in a country $j$ in June 1997, the exchange rate shock associated with that household is simply $E R C H A N G E_{j}$. For households with workers in more than one foreign country in June 1997, the exchange rate shock associated with that household is the weighted average exchange rate change across those countries, with each country's exchange rate weighted by the number of household workers in that country. Of the 1,646 households included in the analysis, 1,485 (90.2\%) had just one member working overseas in June 1997. 140 households (8.5\%) had two, 18 households (1.1\%) had three, and three households $(0.2 \%)$ had four members working overseas in that month.

Because the research question of interest is the impact of shocks experienced by migrants on outcomes in the migrants' source households, the sample for analysis is restricted to households with one or more members working overseas prior to the Asian financial crisis (in June 1997). ${ }^{19}$ It is crucial that $E R S H O C K_{i}$ is defined solely on the basis of migrants' locations prior to the crisis,

\footnotetext{
${ }^{19} \mathrm{ERSHOCK}_{i}$ is obviously undefined for a household without any members working overseas prior to the crisis.
} 
to eliminate concerns about reverse causation (for example, households experiencing positive shocks to their Philippine-source income might be better positioned to send members to work in places that experienced better exchange rate shocks).

In addition, the Philippine economy experienced a decline in economic growth after the onset of the crisis. Annual real GDP contracted by $0.8 \%$ in 1998, as compared to growth of $5.2 \%$ in 1997 and 5.8\% in 1996 (World Bank 2004). The urban unemployment rate (unemployed as a share of total labor force) rose from $9.5 \%$ to $10.8 \%$ between 1997 and 1998, while the rural unemployment rate went from $5.2 \%$ to $6.9 \%$ over the same period (Philippine Yearbook (2001), Table 15.1). Any effects of the domestic economic downturn common to all sample households (as well as effects of the crisis that differ according to households' observed pre-crisis characteristics) will be accounted for in the empirical analysis, as described in the next section.

\section{Empirics: impact of migrant shocks on households}

In this section, I describe the data and sample construction, the characteristics of sample households, the regression specification and some empirical issues, and then present empirical results.

\subsection{Data and sample construction}

The empirical analysis uses data from four linked household surveys conducted by the National Statistics Office of the Philippine government, covering a nationally-representative household sample: the Labor Force Survey (LFS), the Survey on Overseas Filipinos (SOF), the Family Income and Expenditure Survey (FIES), and the Annual Poverty Indicators Survey (APIS).

The LFS is administered quarterly to inhabitants of a rotating panel of dwellings in January, April, July, and October, and the other three surveys are administered with lower frequency as riders to the LFS. Usually, one-fourth of dwellings are rotated out of the sample in each quarter, but the rotation was postponed for five quarters starting in July 1997, so that three-quarters of dwellings included in the July 1997 round were still in the sample in October 1998 (one-fourth of the dwellings had just been rotated out of the sample). The analysis of this paper takes advantage of this fortuitous postponement of the rotation schedule to examine changes in households over the 15-month period from July 1997 to October 1998.

Survey enumerators note whether the household currently living in the dwelling is the same as the household surveyed in the previous round; only dwellings inhabited continuously by the same 
household from July 1997 to October 1998 are included in the sample for analysis. The survey does not include unique identifiers for surveyed individuals; for analysis of individual outcomes, individuals must be matched over time (within households) on the basis of age and gender.

Households are only included in the sample for empirical analysis if they reported having one or more members overseas in June 1997 (immediately prior to the Asian financial crisis). The analysis focuses on migrant households because migrant households are different (as described in the next subsection) from households without migrants, and so the most natural comparison group for a migrant household is the set of other migrant households. In addition, non-migrant households by definition do not experience the exogenous shock of interest (the overseas exchange rate shock). ${ }^{20}$

Because of the need to match households and individuals across survey rounds, it is important to worry about attrition from the sample. At the household level, a mere $5.6 \%$ cannot be followed from July 1997 to October 1998. This is a very low attrition rate for a panel survey, particularly one in a developing country. At the individual level, on the other hand, attrition is higher $(23.0 \%$ for girls, $23.8 \%$ for boys) because tracking must rely on observable individual characteristics rather than a unique code for each individual. Interested readers should refer to the Data Appendix for details on tracking of households and individuals across survey rounds, and for additional information on the surveys.

Attrition is potentially worrisome if it is correlated with the independent variable of interest, the exchange rate shock. Sample selectivity could then lead to biased estimates. As it turns out, however, there is no evidence that attrition is correlated with the exchange rate shock. I run regressions where the sample is households or individuals that I attempt to track from 1997 to 1998. The dependent variable is an indicator variable equal to 1 if the household or individual cannot be tracked through 1998 (and 0 otherwise), and the independent variable of interest is the exchange rate shock. In no regression is the coefficient on the exchange rate shock large in magnitude or statistically significantly different from zero. The details of this analysis are discussed in the Data Appendix (regression results are reported in Appendix Table 4).

\footnotetext{
${ }^{20}$ That said, one could run the main regressions of this paper including both migrant and non-migrant households in the sample, and then set the exchange rate shock to zero for non-migrant households. The estimated effect of the exchange rate shock on various outcomes turns out to be very similar to the results reported in this paper (results available on request).
} 


\subsection{Characteristics of sample households}

Table 3 presents summary statistics for the 1,646 households used in the empirical analysis. The top row displays summary statistics for the exchange rate shock. The mean change in the shock index was 0.41 , with a standard deviation of 0.16 .

The mean number of household overseas workers in June 1997 is 1.11. Median cash receipts from overseas was 26,000 pesos (US\$1,000) in Jan-Jun 1997. Pre-crisis cash receipts from overseas were substantial as a share of household income, with a median of 0.37 .

Households in the sample tend to be wealthier than other Philippine households in terms of their initial (Jan-Jun 1997) income per capita. 51\% of sample households are in the top quartile of the national household income per capita distribution, and $28 \%$ are in the next-highest quartile. Median pre-crisis income per capita in the household is 15,236 pesos (US $\$ 586) .{ }^{21}$ Mean pre-crisis household size is 6.16 members (including overseas members). ${ }^{22} 68 \%$ of sample households are urban, compared to the national figure of $59 \%$.

Reflecting the importance of remittances from overseas, sample households tend to rely less on wage/salary, entrepreneurial, and agricultural income than the typical Philippine household. The mean of pre-crisis wage and salary income as a share of total income is 0.23 (compared with a national average of 0.41 ). The mean of pre-crisis entrepreneurial income as a share of total income is 0.17 (compared with a national average of 0.31). 50 percent of sample households have nonzero entrepreneurial income, compared with a national average of 59 percent. The mean of pre-crisis agricultural income as a share of total income is 0.10 (compared with a national average of 0.27). Only 23 percent of sample household heads work in agriculture, compared with a national average of 37 percent.

\subsection{Regression specification}

In investigating the impact of exchange rate shocks on changes in outcome variables between 1997 and 1998, a first-differenced regression specification is natural:

$$
\Delta Y_{i t}=\beta_{0}+\beta_{1}\left(E R S H O C K_{i}\right)+\varepsilon_{i t}
$$

For household $i, \Delta Y_{i t}$ is the change in an outcome of interest. $E R S H O C K_{i}$ is the exchange

\footnotetext{
${ }^{21}$ When I report US dollars, they are converted from Philippine pesos at the first-half 1997 exchange rate of roughly 26 pesos per US $\$ 1$.

${ }^{22}$ The corresponding pre-crisis (Jan-Jun 1997) national median of income per capita for all households is 7,944 pesos. The national mean household size in July 1997 was 5.27 .
} 
rate shock for household $i$, as defined above in (2). First-differencing of household-level variables is equivalent to the inclusion of household fixed effects in a levels regression; the estimates are therefore purged of time-invariant differences across households in the outcome variables. $\varepsilon_{i t}$ is a mean-zero error term. In all results tables, regressions are ordinary-least-squares, with standard errors clustered according to the June 1997 location of overseas worker. ${ }^{23,24}$

The constant term, $\beta_{0}$, accounts for the average change in outcomes across all households in the sample. This is equivalent to including a year fixed effect in a regression where outcome variables are expressed in levels (not changes), and accounts for the shared impact across households of the decline in Philippine economic growth after the onset of the crisis.

The coefficient of interest is $\beta_{1}$, the impact of a unit change in the exchange rate shock on the outcome variable. The identification assumption is that if the exchange rate shocks faced by households had all been of the same magnitude (instead of varying in size), then changes in outcomes would not have varied systematically across households on the basis of their overseas workers' locations.

While this parallel-trend identification assumption is not possible to test directly, a partial test is possible. An important type of violation of the parallel-trend assumption would be if households with migrants in countries with more favorable shocks were different along certain pre-crisis characteristics from households whose migrants had less favorable shocks, and if changes in outcomes would have varied according to these same characteristics even in the absence of the migrant shocks.

In fact, households experiencing more favorable migrant shocks do differ along a number of pre-crisis characteristics from households experiencing less-favorable shocks. Appendix Table 1 presents coefficient estimates from a regression of the household's exchange rate shock on a number of pre-shock characteristics of households and their overseas workers. Several individual variables are statistically significantly different from zero, indicating that households experienced more favorable exchange rate shocks if they had fewer members, heads who were more educated, less educated migrants, and migrants who had been away for longer periods prior to the crisis. F-tests reject the null that some subgroups of variables are jointly equal to zero: indicators for household per capita income percentiles; indicators for household head's education level;

\footnotetext{
${ }^{23}$ For households that had more than one overseas worker overseas in June 1997, the household is clustered according to the location of the eldest overseas worker. This results in 55 clusters.

${ }^{24}$ Several outcomes of interest are categorical variables taking on the values 1 , 0 , and -1 (such as changes in the asset indicators and net entry into various kinds of entrepreneurship). For all such outcomes in the paper, results from estimation of an ordered probit model are highly consistent with the OLS results.
} 
indicators for household geographic location in the Philippines; overseas workers' months away variables; overseas workers' education variables; and overseas workers' occupation variables.

This correlation between pre-crisis characteristics and the exchange rate shock is only problematic if pre-crisis characteristics are also associated with differential changes in outcomes independent of the exchange rate shocks (that is, if pre-crisis characteristics were correlated with the residual $\varepsilon_{i t}$ in equation 3). For example, suppose that the 1997-98 domestic economic downturn caused small household enterprises to be more likely to fail in households with less-educated heads, so that entrepreneurial incomes rise differentially for better-educated households than for less-educated households in the wake of the crisis. Appendix Table 1 indicates that households with better-educated heads also experienced more-favorable exchange rate shocks. Then the estimated impact of the exchange rate shocks on household entrepreneurial income would be biased upwards.

To check whether the regression results are in fact contaminated by changes associated with pre-crisis characteristics, I also present coefficient estimates that include a vector of pre-crisis household characteristics $\mathbf{X}_{i t-1}$ on the right-hand-side of the estimating equation:

$$
\Delta Y_{i t}=\beta_{0}+\beta_{1}\left(E R S H O C K_{i}\right)+\boldsymbol{\delta}^{\prime}\left(\mathbf{X}_{i t-1}\right)+\varepsilon_{i t}
$$

$\mathbf{X}_{i t-1}$ includes household geographic indicators and a range of pre-crisis household and migrant characteristics. ${ }^{25}$ Inclusion of $\mathbf{X}_{i t-1}$ controls for changes in outcome variables related to households' pre-crisis characteristics. Examining whether coefficient estimates on the exchange rate shock variable change when the pre-crisis household characteristics are included in the regression can shed light on whether changes in outcome variables related to these characteristics are correlated with households' exchange rate shocks, constituting a partial test of the parallel-trend identification assumption.

\footnotetext{
${ }^{25}$ Household geographic controls are 16 indicators for regions within the Philippines and their interactions with an indicator for urban location. Household-level controls are as follows. Income variables as reported in Jan-Jun 1997: $\log$ of per capita household income; indicators for being in 2nd, 3rd, and top quartile of the sample distribution of household per capita income. Demographic and occupational variables as reported in July 1997: number of household members (including overseas members); five indicators for head's highest level of education completed (elementary, some high school, high school, some college, and college or more; less than elementary omitted); head's age; indicator for 'head's marital status is single'; six indicators for head's occupation (professional, clerical, service, production, other, not working; agricultural omitted).

Migrant controls are means of the following variables across household's overseas workers away in June 1997: indicators for months away as of June 1997 (12-23, 24-35, 36-47, 48 or more; 0-11 omitted); indicators for highest education level completed (high school, some college, college or more; less than high school omitted); occupation indicators (domestic servant, ship's officer or crew, professional, clerical, other service, other occupation; production omitted); relationship to household head indicators (female head or spouse of head, daughter, son, other relation; male head omitted); indicator for single marital status; years of age.
} 
In addition, to the extent that $\mathbf{X}_{i t-1}$ includes variables that explain changes in outcomes but that are themselves uncorrelated with the exchange rate shocks, their inclusion simply can reduce residual variation and lead to more precise coefficient estimates.

In most results tables, I therefore present regression results without and with the vector of controls for pre-crisis household characteristics, $\mathbf{X}_{i t-1}$ (equations 3 and 4 ). In nearly all cases, inclusion of the initial household characteristics controls makes little difference to the coefficient estimates, and on occasion actually makes the coefficient estimates larger in absolute value (suggesting that, in these cases, changes in outcome variables related to households' pre-crisis characteristics bias the estimated effect of the shock towards zero). Inclusion of these pre-crisis characteristics controls also often reduces standard errors on the exchange rate shock coefficients.

I also test the parallel-trend identification assumption by asking whether changes in outcome variables prior to the Asian financial crisis are correlated with the future exchange rate shocks in migrant locations after July 1997 (a "false experiment"). Surveys did not collect data on all outcomes of interest in the pre-crisis period, but it is possible to conduct this false experiment for a subset of outcome variables. I describe this exercise in the Empirical Appendix, and find no evidence that changes in outcome variables in the immediately prior 12-month period (July 1996-July 1997) are correlated with future exchange rate shocks occuring after July 1997.

It is important to keep in mind that measurement error in the exchange rate variable will generate attenuation bias, so that the coefficient on the exchange rate shock is likely to be understated in absolute value. While the exchange rates themselves are international financial data and so should be measured well, there is likely to be error because the time periods used in constructing the $E R C H A N G E_{j}$ variable may not correspond exactly with the time period relevant for household decisions. The $E R C H A N G E_{j}$ variable is constructed as the change in the exchange rate from the 12 months preceding July 1997 to the 12 months preceding October 1998, but decision-makers (remittance senders as well as recipients) may consider a shorter or longer history of exchange rates when making decisions, and in addition may place greater weight on more recent months. In addition, because the relevant time periods are likely to vary across households, no alternative constructions of the $E R C H A N G E_{j}$ variable will be perfect. For this reason, the coefficient on the exchange rate shock in all regressions of this paper are likely to be biased towards zero. 


\subsection{Regression results}

This subsection examines the impact of household exchange rate shocks on the following outcomes in sequence: remittance receipts; migrant return rates; household income, consumption, and other disbursements, including educational expenditures; household durable good ownership; child schooling and child labor; household labor supply by type of work; and specific types of entrepreneurial activities.

\subsubsection{Remittance receipts}

I first document that migrants' positive exchange rate shocks in fact were associated with improvements in households' finances, in particular via the remittances households received from their overseas members.

The first row of Table 4, Panel A presents coefficient estimates from estimating equations 3 and 4 when the outcome variable is the change in remittances (cash receipts, gifts, etc. from overseas). The change in remittances variable is the change between the January-June 1997 and April-September 1998 reporting periods, divided by pre-crisis (January-June 1997) household income. (For example, a change amounting to $10 \%$ of initial income is expressed as 0.1.) The change in $\log$ remittances would have been a natural specification, except for the fact that a large number of households (44.5\%) report receiving zero remittances either before or after the crisis. ${ }^{26}$

Remittance receipts as a fraction of total household income in the pre-crisis period was 0.395 on average. The mean change in remittances (as a share of pre-crisis total household income) was 0.151 over the period of analysis (i.e., growth in peso remittances amounted to $15.1 \%$ of initial household income).

Each cell in the regression results columns presents the coefficient estimate on the exchange rate shock variable in a separate regression. Regression column 1 presents results without the inclusion of any other right-hand-side variables, while regression column 2 includes household location fixed effects and the control variables for pre-crisis household and migrant characteristics. (This format - presenting regression results with and without control variables alongside each other - will also be followed in Tables 5, 6, and 7.)

The coefficient on the exchange rate shock in the regressions for cash receipts from overseas is positive in both specifications, and larger in absolute value (36\% larger) and more precisely

\footnotetext{
${ }^{26}$ Dividing by pre-crisis household income achieves something similar to taking the log of an outcome: normalizing to take account of the fact that households in the sample have a wide range of income levels, and allowing coefficient estimates to be interpreted as fractions of initial household income.
} 
measured when control variables are included (in column 2). It seems that households experiencing more favorable exchange rate shocks also have pre-shock characteristics that are associated with declines in remittances over the study period; controlling for these characteristics raises the estimated impact of the exchange rate shock on remittances.

The coefficient on the exchange rate shock in the second column indicates that a one-standarddeviation increase the size of the exchange rate shock (0.16) is associated with a differential increase in remittances of 3.8 percentage points of pre-shock (Jan-Jun 1997) household income. The exchange rate shock is specified as the change in the exchange rate as a fraction of the preshock exchange rate, so the coefficient on the exchange rate shock in column 2 can be used to calculate the implied elasticity of remittances with respect to the exchange rate. This implied elasticity is 0.60 (the coefficient, 0.238 , divided by remittances as a share of pre-crisis household income, 0.395).

An alternative approach to estimating the exchange rate elasticity of remittances would be to regress the change in log remittances on the change in the log exchange rate, while controlling for all pre-crisis variables as in column 2 of Table $4 .{ }^{27}$ The estimated coefficient on the log change in the exchange rate is 0.64 , with a standard error of 0.30 . (Results available from author on request.)

A $10 \%$ improvement in the exchange rate faced by a household's migrants (in Philippine pesos per unit of foreign currency) raises household remittance receipts by $6 \%$. If the amount of foreign currency sent by migrants to their origin households had remained stable from the pre- to postcrisis periods, the elasticity of remittances would have been unity. ${ }^{28}$ So favorable exchange rate movements actually lead remittances to decline when denominated in the foreign currency. The Philippine-peso-remittance elasticity of 0.6 implies that the foreign-currency-remittance elasticity is -0.40 .

\subsubsection{Migrant return rates}

Migrants were also less likely to return to the Philippines when they experienced more positive exchange rate shocks, providing another (indirect) indication that they faced more attractive economic conditions overseas. In the second row of Table 4, Panel A, the outcome variable is the migrant return rate during the 15 months after the crisis (the number of migrants who returned

\footnotetext{
${ }^{27}$ To deal with cases of zero reported remittances, I replace zero remittances with the 10th percentile of the pre-crisis distribution of nonzero remittances (7,000 pesos) before taking logs.

${ }^{28} \mathrm{~A}$ coefficient on the exchange rate shock of 0.395 would have implied unit elasticity. The hypothesis that the coefficient on the exchange rate shock in column 2 is equal to 0.395 is rejected at the $10 \%$ confidence level.
} 
between July 1997 and September 1998, divided by the number of migrants away in June 1997). The mean migrant return rate over the period was 0.136 .

The coefficients on the exchange rate shock in these regressions for the migrant return rate are negative, although the coefficient falls somewhat in magnitude when pre-crisis controls are added. The coefficients are statistically significantly different from zero on both specifications. The coefficient on the exchange rate shock in the second column indicates that a one-standarddeviation increase the size of the exchange rate shock (0.16) is associated with a differential decline of 2.0 percentage points in the return rate of household migrants. ${ }^{29}$

\subsubsection{Household income, consumption, and other disbursements}

What impact do migrant exchange rate shocks have on aggregate household income and consumption? Table 4, Panel B presents coefficient estimates on the exchange rate shock when the outcome variables are total household income and its major components, and total household consumption. Changes in income (consumption) items are changes between the January-June 1997 and April-September 1998 reporting periods, divided by pre-crisis (January-June 1997) household income (consumption).

It is important to reiterate a previous point that these income figures refer only to income received by the household within specific reporting periods. As such, the impact of the exchange rate shocks on within-period household income will give only a partial picture of the true impact on household income, which includes the change in the peso value of future overseas earnings, as well as the change in the peso value of savings that are held overseas (that may not be remitted within the reporting period). Consumption expenditures do not include educational expenditures, durable goods purchases or capital investment in household enterprises.

Household income and consumption experience substantial growth over the period. On average across households, the growth in household income amounts to $25.1 \%$ of initial total household income, while the growth in household consumption amounts to $9.3 \%$ of initial household consumption.

The coefficients on the exchange rate shock in the regressions for total household income are positive in both specifications, and essentially the same in absolute value (within $1 \%$ in size) and more precisely measured when control variables are included (in column 2). Essentially all of the

\footnotetext{
${ }^{29}$ For a more detailed theoretical and empirical treatment of overseas workers' return decisions in these households, see Yang (forthcoming). (The estimated impact of exchange rates on return rates in that paper differ slightly in that they focus on return rates over 12 post-crisis months, rather than 15 months as analyzed here.)
} 
impact of the shock on total household income comes through the change in the 'other sources of income' category, which includes remittances. In turn, the impact of the shock on 'other sources of income' appears to work entirely through the change in remittances: the coefficients and significance levels in the regressions for other sources of income (in Panel B) are essentially the same as those for remittance receipts (in Panel A). The estimated impacts of the exchange rate shocks on wage and salary income and on entrepreneurial income are small in magnitude and not statistically significantly different from zero in all specifications.

There is no indication that aggregate household consumption expenditures were substantially affected by the exchange rate shocks. The coefficients on the exchange rate shock in the household consumption regressions are actually negative in sign, although not statistically significantly different from zero.

The coefficient on the exchange rate shock in the second column indicates that a one-standarddeviation increase the size of the exchange rate shock (0.16) is associated with a differential increase in total household income of 4.2 percent of pre-shock (Jan-Jun 1997) household income.

If exchange rate shocks show no strong relationship with household consumption, how are improvements in households' resources used? In the remainder of Table 4, and in subsequent tables, I provide evidence that favorable exchange rate shocks lead to increases in various types of household investment activity.

Table 4, Panel C examines the impact of exchange rate shocks on households' non-consumption disbursements, expressed as a fraction of initial (Jan-Jun 1997) household consumption. Surveyed households are not explicitly asked about investment-related purchases. I therefore construct a variable which is the sum of several potentially investment-related items: educational expenses, purchases of real property, repayments of loans, and bank deposits. The first row of Panel $\mathrm{C}$ presents coefficient estimates on the exchange rate shock in regressions with this dependent variable. In both specifications, the coefficient is positive and statistically significant at the $10 \%$ level. When the individual components of this variable are the dependent variables of the regression (in the next four rows), the coefficient on the exchange rate shock is consistently positive in sign, and is statistically significantly different from zero in the regressions for educational expenditures.

The coefficient on the exchange rate shock in the second column indicates that a one-standarddeviation increase the size of the exchange rate shock (0.16) is associated with a differential increase in potentially investment-related disbursements of 3.9 percent of pre-shock (Jan-Jun 1997) household consumption. The increase in educational expenditures alone associated with 
such a shock amounts to 0.6 percent of pre-shock household consumption.

The last column of the table displays the elasticity of the given dependent variable with respect to the exchange rate. There is a dramatic difference between the exchange-rate elasticities of consumption versus non-consumption disbursements. The elasticity of consumption with respect to the exchange rate is small in size (and actually negative in sign), and is based on an exchange rate coefficient that is not statistically significantly different from zero. By contrast, the implied elasticity of potentially investment-related disbursements is large, at 1.37, and the elasticity for educational expenditures is 0.55 (elasticities for real property purchases, loan payments, and bank deposits are also large, but are based on coefficient estimates that are not statistically significantly different from zero). A $10 \%$ improvement in the exchange rate faced by a household's migrants leads to a $13.7 \%$ increase in potentially investment-related disbursements. These results stand in stark contrast with research that finds migrant earnings are primarily spent on consumption (e.g., Brown and Ahlburg 1999), and are more in line with existing research documenting a positive relationship between migrant earnings and investment activity, such as Durand et al (1996), Taylor, Rozelle and de Brauw (2003), and Woodruff and Zenteno (2003).

With the exception of educational expenditures, it is admittedly far from certain that the other disbursements I have identified as potentially investment-related are actually used for investment. It therefore makes sense to examine the impact of exchange rate shocks on other items reported in the surveys that may also reveal investment in human capital and entrepreneurship.

\subsubsection{Durable good ownership}

Table 4, Panel D presents coefficient estimates on the exchange rate shock when the outcome variables are changes in an indicator for household ownership of the six durable goods that were recorded in the survey: radio, television, living room set, dining set, refrigerator, and vehicle. The outcome variables take on the values $-1,0$, and $1 .^{30}$

In the initial period, radios are the most commonly-owned durable good, and vehicles the least commonly-owned; the fraction of households reporting ownership of these goods is 0.836 and 0.129 , respectively. Ownership of all the observed durable goods increases over the course of the period of analysis, with the largest increases in ownership observed in radios (a 0.105 increase in the fraction owning) and vehicles (a 0.134 increase).

\footnotetext{
${ }^{30}$ As described in the Data Appendix, durable good ownership data were not recorded in July 1997, so changes in the ownership indicators are between January 1998 and October 1998. If durable good ownership changed by January 1998 in response to the July-December 1997 economic shocks experienced by migrants, the empirical estimates reported for these outcomes are likely to be lower bounds of the true effects.
} 
The coefficients on the exchange rate shock in all regressions except for refrigerators are positive. In the specification without control variables (the first column), the coefficients for television and vehicle ownership are statistically significantly different from zero at conventional levels (respectively, the $10 \%$ and $1 \%$ levels). In the specification with control variables (the second column), the coefficients for television, living room set, and vehicle ownership are statistically significantly different from zero at conventional levels (respectively, the 1\%, 10\%, and 1\% levels).

For ownership of televisions and living room sets, the coefficients become substantially larger and attain higher levels of statistical significance in the specifications with control variables.

In the regression for vehicle ownership, the coefficient becomes slightly smaller in absolute value, falling in magnitude by $14 \%$. It appears that households experiencing more favorable exchange rate shocks also have pre-shock characteristics that are associated with increases in vehicle ownership over the study period. Controlling for these characteristics reduces the estimated impact of the exchange rate shock on vehicle ownership, but the estimate remains substantial in magnitude and statistically significantly different from zero.

The coefficients on the exchange rate shock in the second column indicate that a one-standarddeviation increase the size of the exchange rate shock (0.16) is associated with a differential increase in the likelihood of television, living room set, and vehicle ownership of 1.5, 0.9, and 2.3 percentage points, respectively.

\subsubsection{Human capital investment}

It is of great interest to understand the impact of migrant exchange rate shocks on outcomes related to human capital accumulation: child schooling and child labor. Table 5 presents coefficient estimates on the exchange rate shock when the outcome variables are individual-level changes in student status, total hours worked and hours worked in different types of employment in the week prior to the survey. The 'student indicator' variable is the change in an indicator for 'student' being the person's reported primary activity between July 1997 and October 1998 (this variable takes on the values $-1,0$, and 1). In the analysis of hours worked by type of employment, a combined category for 'hours worked in self employment, as an employer, or as a worker with pay in a family-operated farm or business' is used, because children and young adults are reported to work very few hours in these types of employment separately. Individuals were included in the analysis if they were aged 10-17 in July 1997.

Results are presented for females and males together, and also separately for females and 
males. For each sample results are presented for specifications with and without control variables. Control variables for pre-crisis characteristics include the same household and migrant variables used in Table 4. Because these are individual-level regressions, the controls also include pre-crisis individual characteristics: fixed effects for each year of age, a gender indicator, indicator for single marital status, indicator for 'student' being the person's primary activity, indicator for 'not in labor force', and five indicators for highest schooling level completed.

In the initial period, the fraction of children aged 10-17 classified as 'student' is 0.94, and the mean hours worked in the past week is 1.1. On average over the period of analysis, there is some transition out of student status and into the labor force: the mean change in the 'student' indicator is -0.036 (standard deviation 0.007), and the mean change in hours worked is 0.971 (standard deviation 0.221).

The coefficients on the exchange rate shock in the regressions for the student indicator are all positive in sign, and are statistically significantly different from zero in the specification with control variables in the pooled sample (male and female) and the female subsample. Standard errors are too large, however, to rule out that the coefficient on the exchange rate shock in the male subsample is the same as the coefficient in the female subsample. In both subsamples, the coefficient on the shock is larger in absolute value in the specification with control variables.

The coefficients on the exchange rate shock in the regressions for total hours worked are all negative in sign, and the coefficient is statistically significantly different from zero in the pooled male and female sample (in both specifications), and in the specification with control variables for males. Again, standard errors are too large to reject the hypothesis that the male and female coefficients are identical. In the pooled sample, and for males and females separately, more favorable exchange rate shocks lead to statistically significantly fewer hours of work without pay in family enterprises. In the pooled sample, and for males, more favorable exchange rate shocks lead to statistically significant increases in hours worked in self employment, as an employer, or as a worker with pay in a family-operated farm or business, but this increase is not large enough to offset the overall decline in hours worked. For all statistically significant results related to labor supply, the magnitude of the estimated coefficient is either larger in absolute value or essentially the same in specifications with control variables than in specifications without control variables.

In sum, more favorable shocks are associated with more child schooling and less child labor. The coefficients on the exchange rate shock in the pooled-sample regressions with control variables indicate that a one-standard-deviation increase in the size of the exchange rate shock $(0.16)$ is associated with a differential increase in the likelihood of being a student of 1.6 percentage points, 
and a differential decline in hours worked in the past week of 0.35 hours.

\subsubsection{Household labor supply}

Table 6 presents coefficient estimates on the exchange rate shock when the outcome variables are changes in total hours worked in the household (the sum across all household members) and changes in hours worked in different types of employment in the week prior to the survey, including self-employment and work in household enterprises. In the initial period, mean total hours worked across households is 72.6 hours. Hours worked at the household level is roughly stable over the period of analysis: on average, this figure declines by just -0.68 hours (standard deviation 1.199).

The coefficients on the exchange rate shock in the regressions for total hours worked are positive but not statistically significantly different from zero. The same is true in regressions for hours worked for employers outside the household.

Migrant exchange rate shocks do affect entrepreneurial labor supply. In particular, more favorable exchange rate shocks are associated with increases in hours worked in self employment: the coefficients in these regressions are positive and statistically significantly different from zero. In the specification with control variables (column 2), the coefficient estimate becomes $19 \%$ larger in absolute value and attains the $5 \%$ significance level, compared with the specification without controls (column 1).

The coefficient on the exchange rate shock in the second column indicates that a one-standarddeviation increase the size of the exchange rate shock (0.16) is associated with a differential increase in hours worked in self employment of 1.6 hours per week.

There is also suggestive evidence that hours worked without pay in family-operated farms or businesses declines with more favorable exchange rate shocks (the coefficients for this outcome are negative in sign and relatively large in magnitude), but these results are not statistically significantly different from zero. It may be that better migrant economic conditions are associated with differential shifts out of work without pay and into self employment in household enterprises.

\subsubsection{Entrepreneurial activities}

How did the exchange rate shock affect household entrepreneurial activities? Panel A, Table 7

presents coefficient estimates on the exchange rate shock when the outcome variables are the change in household entrepreneurial income, and the change in an indicator for entrepreneurial 
activity. ${ }^{31}$ The change in entrepreneurial income is the change between the January-June 1997 and April-September 1998 reporting periods, divided by pre-crisis (January-June 1997) total household income.

Prior to the crisis, 50\% of households reported engaging in some entrepreneurial enterprise, and on average the fraction of household income coming from entrepreneurial activities was 0.17. On average over the sample period, entrepreneurial income rose slightly (as a fraction of pre-crisis household income) by 0.023 , and the fraction engaging in any type of entrepreneurship also rose somewhat, by 0.014 .

The exchange rate shock has only a small positive (and statistically insignificant) effect on household entrepreneurial income. While the coefficient on the exchange rate shock in the entrepreneurial activity indicator regression is positive in both specifications, it is not statistically significantly different from zero in the specification with control variables. All told, there is little evidence of a clear, strong relationship between the exchange rate shock and entrepreneurial activity overall.

However, "entrepreneurial activity" is a catch-all term for any type of self employment. It encompasses activities as diverse as farming one's own land, operating a taxi, and running a grocery store. Even if the exchange rate shocks do not have strong effects on entrepreneurship overall, they could affect the types of entrepreneurial activities that households engage in. (Household entrepreneurial activities in the survey are divided into 11 specific types, listed in Appendix Table 2.)

Indeed, it does appear that the exchange rate shocks are significantly associated entry into new entrepreneurial activities. Panel B of Table 7 presents coefficient estimates on the exchange rate shock when the outcome variables are indicators for entry into a new entrepreneurial activity, and for exit from an old entrepreneurial activity. ${ }^{32}$

The exchange rate shock has a positive impact on the likelihood that a household enters a new entrepreneurial activity over the period of analysis, and this effect is statistically significantly different from zero in the specification with control variables. A one-standard-deviation increase the size of the exchange rate shock (0.16) is associated with a differential increase in the likelihood

\footnotetext{
${ }^{31}$ The exact same entrepreneurial income result also appears in Panel B, Table 4. It is simply repeated here for emphasis.

${ }^{32}$ Entry into a new activity is defined as occurring when a household reports engaging in one or more activity from Appendix Table 2 in Apr-Sep 1998, when it was not engaging in the same activity or activities in the initial period (Jan-Jun 1997). Exit from an old activity is defined analogously. There appears to be substantial churn in the types of activities households in which households are engaged: the fraction engaging in a new activity is 0.237 , and the fraction exiting from an old activity is 0.222 .
} 
of entering a new entrepreneurial activity of 2.2 percentage points. In the regression for exit from old activities, the coefficients on the exchange rate shock are negative, but in neither specification are the coefficients statistically significantly different from zero.

What types of activities are households entering when they experience more favorable exchange rate shocks? One might expect that a household income shock should have its main effect on entrepreneurial activities that require some substantial investment of capital, by alleviating credit constraints that may have limited past investment. It therefore makes sense to look at specific types of entrepreneurship in greater detail, to see whether activities that are likely to be more capital-intensive seem more responsive than others to exchange rate shocks. The main focus is on the impact of the shocks on the extensive margin of entrepreneurial activity - whether the household participates at all in specific types of entrepreneurship.

Table 8 examines the impact of the exchange rate shocks on the 11 specific types of entrepreneurial activity listed in Appendix Table 2. The fraction of households that report nonzero income in each type of entrepreneurial activity in the pre-crisis period is displayed in the column prior to the first results column (households can report more than one activity). "Crop farming and gardening" is reported by the largest fraction of households, $21.9 \%$, with "wholesale and retail trade" coming in a close second at 18.4\%. "Transportation and communication services" (8.2\% of households), "livestock and poultry raising" (5.5\%), "community and personal services" $(4.3 \%)$, and "manufacturing" (3.8\%) round out the six most common entrepreneurial activities.

Regression column 1 presents regression results where the outcome variable is an indicator for entry into the given activity: it is equal to 1 if the household reported no income from the given activity prior to the crisis, but nonzero income after the crisis (and 0 otherwise). Column 2 presents regression results where the outcome variable is an indicator for exit from the activity, taking a value of 1 if the household reported nonzero income prior to the crisis but zero income after the crisis (and 0 otherwise). And in column 3, the outcome is net entry into the activity: the indicator for new entry minus the indicator for exit (so that it takes on the values 1,0 , and -1). All regressions include the full set of control variables for household and migrant pre-crisis characteristics. Results reported are coefficients on the exchange rate shock (standard errors in parentheses).

Effects of the exchange rate shock on entrepreneurship are narrowly focused on a few activities. Positive exchange rate shocks lead to greater entry and less exit from entrepreneurship in transportation and communication services: the coefficient on the exchange rate shock for entry (column 1) is positive and statistically significant at the $10 \%$ level, and the coefficient in the 
exit regression (column 2) is negative and nearly the same magnitude (although not statistically significantly different from zero). This leads to a positive and statistically significant effect of the shocks on net entry (column 3). A similar pattern of coefficient signs and statistical significance holds for entry, exit, and net entry into manufacturing entrepreneurship. ${ }^{33}$

The magnitude of the impact of the shocks on net entry into these two activities is large. The relevant coefficients from column 3 indicate that a one-standard-deviation increase (0.16) in the exchange rate shock leads net entry into "transportation and communication services" and "manufacturing" to rise by 1.2 and 0.9 percentage points, respectively. These are sizable effects, considering that the percentage of households undertaking such activities prior to the crisis was just $8.2 \%$ and $3.8 \%$, respectively.

The increase in net entry into transport/communication and manufacturing is also reflected in differential increases in income from these activities in households experiencing better exchange rate shocks. The fourth column of regression results is for regressions of the change in entrepreneurial income from the given activity (expressed as a share of total household income prior to the crisis) on the exchange rate shock. The exchange rate shock leads to positive and statistically significant increases in entrepreneurial income in both "transportation and communication services" and "manufacturing". At the same time, there is very tentative evidence of a decline in entrepreneurial income from "crop farming and gardening" and "wholesale and retail trade". Coefficients on the exchange rate shock in those regressions are both negative but not statistically significantly different from zero at conventional levels (although the coefficient for the "wholesale and retail trade" regression is marginally significant, with a p-value of 0.11). It is possible that - in response to positive exchange rate shocks - households undertaking multiple types of entrepreneurial activities shift resources away from crop farming/gardening and trading activities and towards transportation/communication and manufacturing.

A likely explanation for the positive impact of the exchange rate changes on entrepreneurial activity in transportation/communications and manufacturing is that previous investment in these activities had been hampered by credit constraints, so positive income shocks provide households with the resources to make necessary fixed investments. These types of activities are likely to require non-trivial fixed up-front investments: vehicles are necessary for engaging in transportation services, and manufacturing activities will require physical equipment. Reductions in exit

\footnotetext{
${ }^{33}$ Interestingly, positive exchange rate shocks lead to statistically significant differential increases in exit from fishing and construction. It is not obvious why this should be the case, although one might speculate that households consider these activities particularly difficult or dangerous and take the opportunity to leave these activities when their economic prospects improve.
} 
from these activities in response to positive exchange rate shocks are also consistent with alleviation of credit constraints. Improvements in households' economic prospects may allow them to avoid inefficient liquidation of their productive assets, a phenomenon that can arise when credit markets are imperfect, as in Rosenzweig and Wolpin (1993). The lack of responsiveness of other types of entrepreneurship (such as crop farming/gardening, and wholesale/retail trade) may be due to these activities' not requiring such large up-front fixed investments; indeed, the share of households undertaking these activities prior to the crisis is relatively large.

It would be ideal to have some confirmation that initial lump-sum investments are particularly large in transportation/communications and manufacturing household enterprises. While there is little information in the data on such investments, recall from Table 4, Panel $\mathrm{C}$ that vehicle ownership rises more in households with more positive shocks. This finding supports the idea that exchange rate shocks led to a rise in entrepreneurial income from transportation services by facilitating vehicle purchases (or preventing vehicle disinvestment).

More generally, it is useful to simply examine the relationship between household income or wealth, on the one hand, and participation in various types of entrepreneurship on the other. If initial fixed investments are more important for entrepreneurship type A than for type B, then it should be true that households engaging in entrepreneurial activity A have higher wealth or income levels than those engaging in activity B.

Comparisons of this sort are presented for Philippine households in Appendix Table 3. The table presents results from OLS regressions where the dependent variables are total household income, consumption, and bank deposits (in pesos) in early-to-mid 1997 (prior to the crisis). Independent variables are a constant and indicator variables for participation in 11 different types of entrepreneurship. The sample includes all households observed in the Jan-Jun 1997 Family Income and Expenditure Survey. The constant term represents the mean value of the dependent variable for non-entrepreneurial households, and the coefficients on the indicator variables represent the deviation from that mean value associated with participation in the given type of entrepreneurship. The indicator variables are ordered from top to bottom in terms of the frequency the given type of entrepreneurship among households.

Focusing for the moment on the eight most common entrepreneurial types (those with greater than $1 \%$ prevalence among households), certain patterns emerge. Participation in four of these seven types of entrepreneurship is associated with higher income, consumption, and bank deposits compared to non-entrepreneurial households. Participation in transportation/communication and community/personal services are associated with the highest income/wealth levels, followed by 
manufacturing and then wholesale/retail trade. By contrast, participation in the remaining three types of entrepreneurship - crop farming/gardening, fishing, and forestry - is associated with lower income, consumption, and bank deposits relative to non-entrepreneurial households.

These patterns are consistent with entrepreneurship in transportation/communication and manufacturing requiring higher initial lump-sum investments. While community/personal services is also associated with higher income/wealth levels, exchange rate shocks may not stimulate more entry into these activities (at least in the short run) because this category includes occupational types that involve substantial educational investments (such as medicine, dentistry, and law).

If one expands the comparison to include the three least-prevalent entrepreneurial types, participation in construction and in "activities not elsewhere classified" are associated with the highest income, consumption, and bank deposits. The fact that such small fractions of households participate in these activities $(0.2 \%$ for construction, $0.8 \%$ for "activities not elsewhere classified") may indicate that there are other relevant barriers to entry, such as specialized skills or connections. It may also be that entry into these activities requires such high initial fixed investments that even the large exchange rate shocks examined here are not sufficient to raise households over the investment threshold.

It is important to keep in mind that these comparisons are merely suggestive, and allow for several alternative explanations. For example, certain types of entrepreneuship might simply be more lucrative, and lead to higher income levels. Also, omitted variables such as entrepreneurial ability could lead both to higher income and to entry into particular activities.

\subsubsection{Robustness checks and alternative specifications}

In this section, I assess the evidence for alternative interpretations of the empirical results, and examine the sensitivity of the results to exclusion of households with migrants in various countries.

\subsubsection{Clarifying the interpretation of the empirical results I argue that the impacts} of exchange rate shocks on the various outcomes discussed above are most plausibly interpreted as household responses to transitory income shocks. In addition, the exchange rate shocks themselves appear to be the primary causal factor behind the income changes, rather than real economic shocks that might have been correlated with the exchange rate shocks. I present here empirical evidence that bolsters this interpretation of the results.

More favorable exchange rate shocks also reduce migrants' return rates (as demonstrated in Panel A of Table 4), and this raises the concern that it might be inappropriate to interpret the 
exchange rate shocks as acting solely via shocks to household income. In particular, a migrant's decision to delay return might affect household investments, in and of itself. Longer absences by migrant parents may detrimentally affect child schooling, for example. Also, a migrant who stays overseas cannot supply labor to a household enterprise, potentially dampening household entrepreneurial effort (particularly when labor markets are imperfect). These examples suggest that the concurrent changes in migrant return rates could lead the positive impact of the exchange rate shocks to be understated (relative to a situation where migrant returns did not respond to the shocks, so that the shocks only affected household investments via an income channel).

To gauge whether migrant returns (in and of themselves) might be clouding the income-shock interpretation of the exchange rate changes, it is useful to examine how the estimated impact of the exchange rate shocks changes when controlling for each household's migrant return rate between 1997 and 1998. If migrant decisions to delay return have negative effects on other outcome variables, then because the exchange rate shock and migrant returns are negatively related, inclusion of a control for migrant returns would make the coefficient on the exchange rate shock larger in absolute value. As in Panel A, Table 4, the migrant return rate is the number of migrants who returned between July 1997 and September 1998, divided by the number of migrants away in June 1997.

Even if one believes that the estimated impact of the exchange rate shocks acts predominantly via changes in household income, an additional issue of interpretation remains: are the exchange rate shocks themselves the primary causal factor, or are the regression coefficients also influenced by real economic shocks that were correlated with the exchange rate movements during the Asian financial crisis? This question is important for assessing the generality of this paper's empirical results. If the exchange rate shocks themselves are the primary causal factor (rather than real economic shocks), then this paper's results can be more readily applied to other cases where migrants experience exchange rate movements that are not accompanied by changes in real economic conditions.

To assess whether correlated changes in real economic conditions are contributing to the estimated effect of the exchange rate shocks, it makes sense to examine how the estimated impact of the exchange rate shocks changes when controlling for measures of real economic shocks. I use two measures of real economic shocks. First, to account for job terminations overseas, I control for a "migrant job loss" indicator, which is equal to one if the household reported that migrant member(s) experienced a job loss in 1998 (the mean of this indicator is 0.075). Second, to measure changes in overall economic activity overseas, I use the change in the natural log of GDP between 
1996 and 1998 in migrant member(s) June 1997 locations. This variable has a mean (std.dev.) of 0.003 (0.0387). ${ }^{34}$ For the six largest location countries of Philippine migrants, the changes in log GDP are as follows: Saudi Arabia, 0.017; Hong Kong, -0.055; Taiwan, 0.045; Singapore, 0.001; Japan, -0.011; and United States, 0.043.

Of course, the migrant return rate and (potentially) migrant job loss are household choice variables, so including them as independent variables can lead to biased estimates of the coefficient on the exchange rate shock (Angrist and Krueger 1999), adding additional ambiguity to the interpretation of the empirical results. That said, if inclusion of these household choice variables in the regressions leads to little or no change in the coefficient on the exchange rate shock, it would lend support for rejecting the various alternative interpretations just outlined. (In this case, it is also possible - albeit unlikely - that several sources of potential bias exactly offset each other, so that the coefficient on the exchange rate shock is unchanged.)

Table 9 presents the results of this exercise, for changes in remittances as well as five of the main household investment outcomes between 1997 and 1998. Four of the outcomes are at the household level: the change in remittances, entry into a new entrepreneurial activity, net entry into transportation/communication entrepreneurship, and net entry into manufacturing entrepreneurship. The other two outcomes are at the individual child level: the change in student status, and the change in hours worked. Both the household- and individual-level samples are slightly smaller than in previous tables because data on GDP are not available in all migrant locations overseas (such as the Northern Marianas Islands). Two regressions are presented for each of these outcomes: first, the coefficient on the exchange rate shock in a regression without the additional control variables is presented for comparison; and second, the exact same regression but with the added controls. To maximize comparability of the exchange rate shock coefficients, the first regression in each pair excludes observations with missing data on the added control variables. All regressions in the table are for the specification that includes control variables for household- and migrant-level pre-crisis characteristics (plus individual characteristics in the individual-level regressions). The question of interest is whether the coefficient on the exchange rate shock changes when the added controls are included in the regression.

It turns out that including controls for migrant returns, migrant job loss, and the change in log GDP has quite modest effects on the exchange rate shock coefficient. For example, in the remittance regressions, the coefficient on the exchange rate shock is 0.234 in the regression

\footnotetext{
${ }^{34}$ In the few cases where a household has migrant members in multiple countries, I simply take the mean of the change in log GDP across migrant members.
} 
without the additional controls, and 0.296 with the additional controls. In the regressions for net entry into new entrepreneurial activity, the corresponding coefficients are 0.139 and 0.128 , and in the schooling regressions the coefficients are 0.091 and 0.093 , respectively. In all cases, the coefficient on the exchange rate shock remains statistically significantly different from zero at conventional levels when the additional controls are added.

Two conclusions emerge from this analysis. First, the estimated impact of the exchange rate shock on the dependent variables of interest are plausibly interpreted as acting predominantly via changes in household income, rather than via the migrant return channel. Second, the exchange rate shocks themselves are likely to be the primary causal factor behind the changes in household investment outcomes, rather than the real economic shocks (such as job terminations or the change in economic output) that might be correlated with the exchange rate shocks.

Some of the coefficients on the added controls are also worth noting. Migrant returns are associated with increases in child schooling and reductions in child labor, and the coefficients on the migrant return rate for both dependent variables are statistically significantly different from zero. A migrant return rate of $1(100 \%)$ is associated with an increase of 3.8 percentage points in the likelihood of staying in school, and a reduction in hours worked per week of 1.4 hours for children aged 10-17. One interpretation of these results is that returned migrants devote labor hours to household enterprises in place of children, reducing child labor hours and raising their school attendance. ${ }^{35}$ Migrant returns are also associated with statistically significant increases in remittance receipts. Migrant job losses are associated with statistically significant declines in remittances sent home, but have little relationship with the household investment outcomes. The change in log GDP variable is inconsistently signed, and is not statistically significantly different from zero in any of the regressions.

At first blush, it may be surprising that migrant returns and migrant job losses are associated with changes in remittances, but for the most part are not associated with corresponding changes in household investment. But for several reasons, these patterns may be sensible. The positive relationship between remittances and migrant returns may simply reflect the fact that migrants transfer accumulated overseas savings to their origin households upon returning home. If this is the case, then the only aspect of the household's finances that changes when migrants return

\footnotetext{
${ }^{35}$ Additional analysis (not reported in tables, but available from author on request) reveals that the return of mothers in has a larger positive association with schooling than the return of other family members. In particular, returns of mothers have statistically significantly larger relationships with child schooling than returns of either fathers or sons. The coefficient on mother returns is larger than that on daughter returns, but the difference is not statistically significantly different from zero. (The coefficient on daughter returns is larger than that on returns of fathers or sons, but these differences are also not statistically significant.)
} 
is the location - and not the amount - of household wealth. Thus it should not be surprising if household investments remain relatively constant as well.

When it comes to migrant job losses, migrants may in practice be able to find replacement jobs quite rapidly. While job loss does increase the likelihood of return, it is far from true that job loss always leads to return: in $70 \%$ of households reporting a migrant job loss, no migrants return. (Results available from author on request.) In other words, it is likely that the majority of migrants who experience a job loss find or expect to find other overseas jobs. Remittances may thus decline temporarily, but may be expected to increase again subsequently. Furthermore, migrant job loss affects only current earnings, but has no direct effect on past savings accumulated overseas. By contrast, exchange rate shocks affect not just current earnings but also the Philippine-peso value of savings held overseas. For all these reasons, it is sensible that exchange rate shocks have a greater effect on household investments than do job losses.

\subsubsection{Robustness to exclusion of individual countries One might be concerned that} results are being driven by changes in a few outlier countries. To check whether this is the case, I run regressions for six key outcome variables (the same ones examined in Table 9) where I exclude households with migrants in the top 20 migrant destinations one by one from the sample.

Results are presented in Appendix Table 5. Each cell of the table presents results from a separate OLS regression. Each regression includes household location fixed effects and controls for household and migrant characteristics. Regressions for child outcomes include individual-level control variables.

In the first row, the results from the original full sample (with no countries excluded) are displayed for ease of comparison. In the subsequent rows, households with migrants in a given country are excluded from the sample, and coefficient estimates on the exchange rate shock are

presented. Scanning down the columns of coefficients for each dependent variable, the point estimates appear quite stable, and levels of statistical significance nearly always exceed the $10 \%$ level.

The only exception is in the 8th row, where Malaysia is excluded: coefficient estimates on the exchange rate shock in the regressions for net entry into manufacturing and for the change in student status have declined enough that they are no longer statistically significantly different from zero. That said, point estimates remain positive in sign, and the exchange rate shock is still found to have a statistically significant positive effect on the other dependent variables.

That some results become statistically insignificant with the exclusion of Malaysia is not 
surprising, and should not be worrisome. Malaysia suffered one of the worst exchange rate shocks and is the seventh-largest migrant destination (only Korea had a worse shock, and it is a substantially smaller migrant destination.) Malaysia therefore contributes a large amount of variation in the independent variable of interest, the exchange rate shock, and so it is quite natural that certain results become slightly weaker when households with migrants in Malaysia are excluded from the sample.

\section{Conclusion}

Due to their locations in a wide variety of countries, overseas Filipino workers were exposed to exchange rate shocks of various sizes in the wake of the Asian financial crisis. This paper takes advantage of this unusual natural experiment to identify the impact of migrant income shocks on a range of investment outcomes in Philippine households, such as child schooling, child labor, and entrepreneurial activity.

A number of studies of international migration conclude that remittances are primarily consumed and not invested. By contrast, this paper finds that large, exogenous shocks to the income and wealth of Philippine migrant households, which manifest themselves in part via changes in remittances, have negligible effects on household consumption but large effects on various types of household investments. Households experiencing more favorable exchange rate shocks raise their non-consumption disbursements in several areas likely to be investment-related (in particular in educational expenditures), keep children in school longer, take children out of the labor force, raise their hours worked in self-employment, and are more likely to start relatively capital-intensive entrepreneurial enterprises.

The findings presented here shed light on how developed countries' policies affecting migrant workers can affect households in poor countries. This paper's findings are directly applicable to predicting the impact of reductions in the cost of sending remittances, as such cost reductions are effectively an improvement in the exchange rate faced by remittance senders. More generally, this paper suggests that rich-country policies expanding employment opportunities for workers from overseas can stimulate human capital investment and entrepreneurship in poor-country households. For example, policies that allow currently undocumented workers to obtain legal working papers, such as those currently being debated in the United States, should expand the earnings opportunities of migrants in the US and thus human capital and entrepreneurial investments in migrants' origin households. By contrast, increasing enforcement against illegal immigrants or 
eliminating temporary work permissions for overseas migrants should reduce migrant earnings opportunities and thereby discourage such origin-household investments.

In addition, for migrant source countries in the developing world, this paper sheds light on the potential impact of policies that facilitate migrant savings overseas and stimulate remittances. For example, the Mexican government issues to its nationals in the United States official identity cards (matriculas consulares) that many financial institutions accept as proof of identity for the purpose of opening a bank account. If matriculas consulares lead to increases in migrant savings rates and remittances sent home, this paper's results suggest that the Mexican government's policy could also bolster origin-household investments in children and small enterprises.

Further research taking advantage of exchange rate shocks as exogenous variation should be worth pursuing, in particular those related to the migration flows themselves. Yang (forthcoming) examines in greater detail the interrelationship between return migration and household investment activities in response to the exchange rate shocks.

Migration outflows are also of interest. Are new migrant outflows biased towards countries whose currencies appreciated more post-1997? Do existing migrants shift their locations from countries experiencing negative exchange rate shocks (like Korea and Malaysia) to those where exchange rates remained stable (such as Saudi Arabia)? Are certain types of migrants, such as the more-educated, better able to adjust their overseas destinations post-1997? I consider these questions important areas for future research.

\section{Empirical appendix: False experiment}

It is important to investigate whether the empirical results may be biased by pre-existing trends in outcomes across households whose migrants are in different countries (as discussed in subsection 4.3). Here, I test the parallel-trend identification assumption by asking whether changes in several outcome variables from 1996 to 1997 (prior to the crisis-induced exchange rate shocks) are correlated with the future exchange rate shocks in migrant locations after July 1997 (a "false experiment").

Recall (as described in Section 4.1) that the opportunity to track the 1,646 sample households in the main analyses of this paper from July 1997 to October 1998 arose with the fortuitous postponement of the survey's normal quarterly rotation schedule for several quarters starting July 1997. Prior to July 1997, the normal household rotation schedule was followed, so that none of the 1,646 sample households were surveyed in 1996. However, it is possible to conduct the false experiment for 423 households that remained continuously in the survey from July 1996 to October 1997 and that had a migrant overseas immediately prior to the crisis in June 1997. This 423-household false experiment sample is completely non-overlapping with the 1,646-household

main sample, but results using the 423-household sample should still be useful as it was selected 
using sampling methods similar to the main sample.

The false experiment involves estimating equations (3) and (4) for the 423-household sample, but where the changes in outcome variables are from 1996-1997 instead of 1997-1998. The absence of statistically significant relationships between future exchange rate shocks and past changes in outcome variables would provide support for the parallel-trend identification assumption.

In 1996-1997, it is only possible to examine changes in outcome variables reported in the Survey on Overseas Filipinos or in the Labor Force Survey. It is not possible to examine changes in income or expenditures, as no such data were collected in $1996 .{ }^{36}$ The first outcome of interest is the change in remittances from October 1996 and October 1997 (from the Survey on Overseas Filipinos conducted in those months), expressed as a fraction of Jan-Jun 1997 household income (from Family Income and Expenditure Survey). ${ }^{37}$ The remaining outcome variables are changes in household hours worked in the past week by non-overseas household members, between July 1996 and July 1997 (from the Labor Force Survey), in total as well as in the employment types examined in Table 6.

Results are presented in Appendix Table 6. Each cell in regression columns 1-2 presents the coefficient estimate on the future (Jul 1997 - Oct 1998) exchange rate shock in a separate OLS regression. The first column presents coefficient estimates when no control variables are included in the regression, while the second column presents coefficient estimates including control variables. ${ }^{38}$ As in the main results tables, standard errors are in parentheses, clustered by location country of household's eldest overseas worker.

The results confirm that pre-crisis improvements in outcome variables are not correlated with post-crisis exchange rate shocks in household migrant locations. In the first column, the only coefficient on the exchange rate shock that is significantly different from zero (at only the $10 \%$ level) is the coefficient in the regression for hours worked "as employer in own family-operated farm or business," and the sign is actually negative. In the second column, when control variables are included in the regression, no coefficients on the exchange rate shock are statistically significantly different from zero.

It should be noted that the smaller sample size leads coefficient estimates in this false experiment to be relatively large compared with the main results tables. A somewhat different false experiment with a larger sample size is implemented in a companion paper, Yang (forthcoming). This alternative false experiment uses retrospectively-reported data on migration from the October 1997 Survey on Overseas Filipinos and therefore can be conducted with the full sample of households observed in the main analyses. This alternative false experiment finds no large or statistically significant relationship between return migration in 1996-1997 and post-1997 exchange rate shocks. In sum, there is no evidence that changes in outcome variables in the 1996-1997 are correlated with exchange rate shocks occuring after July 1997, which supports the parallel-trend identification assumption.

\footnotetext{
${ }^{36}$ Prior to 1997 , data on income, expenditures, and detailed entrepreneurial activities were most recently collected in the 1994 Family Income and Expenditure Survey, for an entirely non-overlapping cross-sectional sample of households.

${ }^{37}$ The second observation for remittances occurs in October 1997, which is some three months after the start of the crisis. Because remittances could in principle have started to respond by October 1997, this test is biased towards finding an effect of the post-crisis exchange rate shock on 1996-1997 remittance changes.

${ }^{38}$ The control variables (listed in the note to the table) are similar to those included in the main results tables. The only difference is that it is not possible to include controls for household income due to the absence of 1996 income data.
} 


\section{Data appendix}

\subsection{Data sets}

Four linked household surveys were provided by the National Statistics Office of the Philippine government: the Labor Force Survey (LFS), the Survey on Overseas Filipinos (SOF), the Family Income and Expenditure Survey (FIES), and the Annual Poverty Indicators Survey (APIS). ${ }^{39}$

The Labor Force Survey (LFS) collects data on primary activity (including 'student'), hours worked in the past week, and demographic characteristics of household members aged 10 or above. These data refer to the household members' activities in the week prior to the survey. The survey defines a household as a group of people who live under the same roof and share common food. The definition also includes people currently overseas if they lived with the household before departure. As collected in the LFS, hours worked refers only to work for pay or profit, whether outside or within the household, or work without pay on a family farm or enterprise; it excludes housekeeping and repair work in one's own home.

The Survey on Overseas Filipinos (SOF) is administered in October of each year to households reporting in the LFS that any members left for overseas within the last five years. The SOF collects information on characteristics of the household's overseas members, their overseas locations and lengths of stay overseas, and the value of remittances received by the household from overseas in the last six months (April to September).

In the analysis, I use the July 1997 and October 1998 rounds of the LFS and the October 1997 and October 1998 rounds of the SOF. Because 1997 remittances in the SOF refer to an AprilSeptember reporting period, the SOF remittance data cannot be used to determine a household's level of remittances prior to the July 1997 Asian financial crisis. So I obtain data on cash receipts from overseas from the Family Income and Expenditure Survey (FIES), which was conducted in July 1997 and January 1998. This dataset records all household income sources (including cash receipts from overseas) separately for January to June 1997 and July to December 1997, neatly dividing the year into pre- and post-crisis halves. I obtain a household's initial (Jan-Jun 1997) remittances from the FIES.

Data on detailed income sources, consumption, other disbursements are available for the pre-crisis period (Jan-Jun 1997) from the July 1997 FIES. Data on detailed income sources, consumption, other disbursements, and durable good ownership are available for the post-crisis period (Apr-Sep 1998) from the October 1998 Annual Poverty Indicators Survey (APIS). While educational expenditures are recorded in the consumption portion of the FIES and APIS, in this paper I consider educational expenditures separately as an investment expense (and not as consumption). Data on durable good ownership and housing unit amenities in the pre-crisis period is unavailable in the July 1997 round of the FIES; these data were only recorded in the January 1998 survey. Therefore, analyses of changes in assets examine changes from January 1998 (from the FIES) to October 1998 (from the APIS). To the extent that durable good ownership already changed by January 1998 in response to migrant shocks, the empirical estimates reported for these outcomes are likely to be lower bounds of the true effects.

Data on cash receipts from overseas (remittances) in the second reporting period (Apr-Sep 1998) are available in both the APIS and the SOF (both conducted in October 1998). All analyses of cash receipts from overseas use data from the SOF for the second reporting period because this source is likely to be more accurate (the SOF asks for information on amounts sent by each household member overseas, which are then added up to obtain total remittance receipts; by contrast, the APIS simply asks for total cash receipts from overseas). Total household income in

\footnotetext{
${ }^{39}$ Use of the data requires a user fee, and the datasets remain the property of the Philippine government.
} 
Apr-Sep 1998 (obtained from the APIS) is adjusted so that the remittance component reflects data from the SOF.

Monthly exchange rate data (used in constructing the exchange rate shock variable) were obtained from Bloomberg L.P.

The sample used in the empirical analysis consists of all households meeting the following criteria:

1. The household is inferred to have one or more members working overseas in June $199 \%$. Using the October 1997 SOF, I identify households that had one or more members working overseas in June 1997, and identify the locations of these overseas members. (See the next subsection for the exact procedure.)

2. The household's dwelling was also included in the October 1998 LFS/SOF. As mentioned above, one-quarter of households in the sample in July 1997 had just been rotated out of the sample in October 1998.

3. The same household has occupied the dwelling between July 1997 and October 1998. This criterion is necessary because the Labor Force Survey does not attempt to interview households that have changed dwellings. Usefully, the LFS dataset contains a field noting whether the household currently living in the dwelling is the same as the household surveyed in the previous round.

4. The household has complete data on pre-crisis control and outcome variables (recorded July 1997).

5. The household has complete data on post-crisis outcome variables (recorded October 1998).

Of 30,744 dwellings that the National Statistics Office did not rotate out of the sample between July 1997 and October 1998 (criterion 2), 28,152 (91.6\%) contained the same household continuously over that period (criterion 3). Of these households, 27,768 (98.6\%) had complete data for all variables used in the analysis (criteria 4 and 5). And of these 27,768, 1,646 (5.9\%) had a member overseas in June 1997 (criterion 1). These 1,646 households are the sample used in the empirical analysis.

Constructing the sample on the basis of Criteria 1, 2, and 4 does not threaten the validity of the empirical estimate of the impact of the migrant economic shocks on households. Criteria 1 and 4 are based on pre-shock characteristics of the surveyed households, and criterion 2 comes from the predetermined rotation schedule established by the National Statistics Office.

It is important to check whether sample selection on the basis of Criteria 3 or 5 may have been affected by the independent variable of interest (shocks experienced by migrant members) because household propensities to change dwellings or to misreport information in the survey may have been affected by the shocks. Attrition from the household sample due to these criteria should not generate biased coefficient estimates if such attrition is uncorrelated with the shocks.

Appendix Table 4 (Part A) presents results from household-level regressions where the dependent variable is an indicator for attrition from the sample due to Criteria 3 or 5 . The sample in the regression is all households satisfying Criteria 1, 2, and 4. 5.6\% of households satisfying Criteria 1, 2, and 4 fail to satisfy either Criteria 3 or 5 . The reported coefficient is that on the migrant exchange rate shock variable. The regression controls for location fixed effects and pre-crisis household and overseas worker characteristics (see Table 4 for a list of these control variables). The coefficient is not statistically significantly different from zero and is very small in magnitude (.008). There is no indication that attrition due to Criteria 3 or 5 is associated with the shocks, and so allowing these criteria play a role in determining the sample for analysis should not threaten the internal validity of the estimates. 


\subsection{Determining pre-crisis location of overseas household members}

In this subsection I describe the rules used to determine if a particular individual in the October 1997 Survey on Overseas Filipinos was overseas in June 1997, and if so, what country the person was in. Among other questions, the SOF asks:

1. When did the family member last leave for overseas?

2. In what country did the family member intend to stay when he/she last left?

3. When did the family member return home from his/her last departure (if at all)?

These questions unambiguously identify individuals as being away in June 1997 (and their overseas locations) if they left for overseas in or before that month, and returned afterwards (or have not yet returned). Unfortunately, the survey does not collect information on stays overseas prior to the most recent one. So there are individuals who most recently left for overseas between June 1997 and the survey date in October 1997, but who were likely to have been overseas before then as well. Fortunately, there is an additional question in the SOF that is of use:

4. How many months has the family member worked/been working abroad during the last five years?

Using this question, two reasonable assumptions allow me to proceed. First, assume all stays overseas are continuous (except for vacations home in the midst of a stay overseas). Second, assume no household member moves between countries overseas. When making these two assumptions, the questions asked on the SOF are sufficient to identify whether a household had a member in a particular country in June 1997.

For example, a household surveyed in October 1997 might have a household member who last left for Saudi Arabia in July 1997 and had not yet returned from that stay overseas. If that household member is reported as having worked overseas for 4 months or more, the first assumption implies the person first left for overseas in or before June 1997. The second assumption implies that the person was in Saudi Arabia.

89.8\% of individuals identified as being away in June 1997 (and their overseas locations) were classified as such using just questions 1 to 3 above. The remaining $10.2 \%$ of individuals identified as being away in June 1997 (and their locations) relied on question 4 above and the two allocation assumptions just described. ${ }^{40}$

\subsection{Matching individuals across survey rounds}

In the surveys used in the empirical analysis, it is possible to follow households over time as long as they remain in the same dwelling. However, these data do not explicitly track individuals across survey rounds (there is no unique identifier for individuals). Therefore, when the outcome of interest in the empirical analysis is a change for individual children (schooling and labor supply), I match children within households between the July 1997 and October 1998 survey rounds using their reported age and gender.

Because children of the household head should be more likely to remain resident in the household between the two survey rounds (and thus should generate a higher-quality match), I limit the samples in each period to children of household heads. I first look for 'perfect matches', matches between individuals in the two survey rounds who have the same gender, and where the individual observed in October 1998 reports being one year older (age $t+1)$ than the person observed in July 1997 (age $t$ ).

Because there is likely to be substantial reporting/measurement error in age, I also allow 'imperfect matches': matches between an individual observed in July 1997 (age $t$ ) and the same-

\footnotetext{
${ }^{40}$ Empirical results are not substantially affected when analyses are conducted only on the households where all overseas workers are unambiguously assigned to overseas locations using questions 1,2 , and 3 above.
} 
gendered individual in the household in October 1998 who is closest in to the July 1997 individual's age plus one (closest to age $t+1)$. I allow imperfect matches only if the matched child's age in October 1998 is no more than 2 years different from age $t+1$. I make no attempt to match individuals below the age of 10 in July 1997, as no data is collected on these individuals for the outcome variables of interest.

Whenever more than one match occurs for a particular child within a household (if one individual in July 1997 matches with two or more individuals in the same household in October 1998, or if more than one person in the household in July 1997 has the same age-gender combination), I do not attempt to resolve the match ambiguity and simply drop the given household from the sample altogether. These situations are rare, and in any case should be uncorrelated with migrant exchange rate shocks. As a quality check, I make sure each matched child's education levels across the two survey rounds are reasonable: I disallow matches where education levels change by more than two levels between the two rounds.

Of all children observed in July 1997, 68\% were matched with an individual in the same household in October 1998 using the procedure just described. This figure includes attrition of entire households (due to Criteria 3 and 5 described in Appendix section 7.1 above) as well as unsuccessful individual matches. The successful matches used in the empirical analysis are roughly evenly split between 'perfect' and 'imperfect' matches.

Attrition from the sample of children (due to failed matches) should not generate biased coefficient estimates if attrition is random with respect to the independent variable of interest, the migrant exchange rate shock. Indeed, there is no indication that the incidence of failed matches is associated with these shocks among children who would have been included in the sample for analysis if not for the failed match. Appendix Table 4 (Panels B and C) presents results from individual-level regressions where the dependent variable is an indicator for attrition from the sample due to failed matching, for males and females separately. (Children are included in this regression if the individual's household satisfied Criteria 1, 2, and 4, as described in Appendix section 7.1 above, and if the individual had complete data on individual characteristics in July 1997.) Reported coefficients are those on the migrant exchange rate shock. All regressions control for location fixed effects and pre-crisis individual, household, and overseas worker characteristics. Neither coefficient is statistically significantly different from zero, providing no reason to worry that sample selection on the basis of the exchange rate shock is occurring.

\section{References}

Adams, Richard H., Jr., 'Remittances, Investment, and Rural Asset Accumulation in Pakistan,' Economic Development and Cultural Change, Vol. 17, No. 1, 1998, pp. 155-173.

Ahlburg, Dennis, Remittances and Their Impact : A Study of Tonga and Western Samoa. Canberra: National Centre for Development Studies, Research School of Pacific Studies, the Australian National University, 1991.

Angrist, Josh and Alan Krueger, 'Empirical Strategies in Labor Economics,' in Orley Ashenfelter and David Card, eds., Handbook of Labor Economics, Volume 3A. Amsterdam: North-Holland, 1999.

Baland, Jean-Marie and James A. Robinson, 'Is Child Labor Inefficient?' Journal of Political Economy, Vol. 108, No. 4, 2000, pp. 663-679. 
Basu, Kaushik and Pham Hoang Van, 'The Economics of Child Labor,' American Economic Review, Vol. 88, No. 3, June 1998, pp. 412-427.

Becker, Gary, "A Theory of the Allocation of Time," Economic Journal, Vol. 75, September 1965, pp. 493-517.

Beegle, Kathleen, Rajeev H. Dehejia, and Roberta Gatti, 'Child Labor and Agricultural Shocks,' Journal of Development Economics, forthcoming.

Bhagwati, Jagdish, 'Borders Beyond Control,' Foreign Affairs, Vol. 82 (1), January/February 2003, pp. 98-104.

Birdsall, Nancy, Dani Rodrik, and Arvind Subramanian, 'How to Help Poor Countries,' Foreign Affairs, Vol. 84 (4), July/August 2005, p. 136.

Borjas, George, 'The Economic Analysis of Immigration,' in Orley Ashenfelter and David Card, eds., Handbook of Labor Economics, Vol. 3A, North-Holland, 1999, pp. 1697-1760.

Brown, Richard P.C., 'Migrants' Remittances, Savings, and Investment in the South Pacific', International Labour Review, Vol. 133, No. 3, 1994, pp. 347-367.

Brown, Richard P.C. and Dennis A. Ahlburg, 'Remittances in the South Pacific,' International Journal of Social Economics, Vol. 26, No. 1/2/3, 1999, pp. 325-344.

Cariño, Benjamin, 'Introduction,' in Benjamin Cariño, ed., Filipino Workers on the Move: Trends, Dilemmas, and Policy Options. Manila: Philippine Migration Research Network, 1998.

Chiquiar, Daniel and Gordon Hanson, 'International Migration, Self-Selection, and the Distribution of Wages: Evidence from Mexico and the United States,' Journal of Political Economy, Vol. 113, No. 2, April 2005, pp. 239-281.

Corsetti, Giancarlo, Paolo Pesenti, and Nouriel Roubini, 'What Caused the Asian Currency and Financial Crisis? Part II: The Policy Debate,' NBER Working Paper 6834, December 1998.

Cox-Edwards, Alexandra and Manuelita Ureta, 'International Migration, Remittances, and Schooling: Evidence from El Salvador,' Journal of Development Economics, Vol. 72, 2003, pp. 429-461.

Durand, Jorge, William Kandel, Emilio A. Parrado, and Douglas S. Massey, 'International Migration and Development in Mexican Communities,' Demography, Vol. 33, No. 2, May 1996 , pp. 249-264.

Duryea, Suzanne, David Lam, and Deborah Levison, 'Effects of Economic Shocks on Children's Employment and Schooling in Brazil,' Population Studies Center Research Report No. 03-541, Institute for Social Research, University of Michigan, December 2003.

Dustmann, Christian, and Olivier Kirchkamp, 'The Optimal Migration Duration and Activity Choice After Re-migration,' Journal of Development Economics, Vol. 67, 2002, pp. 351-372.

Frankenberg, Elizabeth, James P. Smith, and Duncan Thomas, 'Economic Shocks, Wealth, and Welfare,' Journal of Human Resources, 2003. 
Grindle, Merilee, Searching for Rural Development: Labor Migration and Employment in Mexico. Ithaca: Cornell University Press, 1988.

Hurst, Eric and Annamaria Lusardi, 'Liquidity Constraints, Household Wealth, and Entrepreneurship,' Journal of Political Economy, Vol. 112, No. 2, April 2004, pp. 319-347.

Ibarraran, Pablo and Darren Lubotsky, 'Mexican Immigration and Self-Selection: New Evidence from the 2000 Mexican Census,' mimeo, Bank of Mexico and University of Illinois, May 2005.

Jacoby, Hanan, and Emmanuel Skoufias, 'Risk, Financial Markets, and Human Capital in a Developing Country,' Review of Economics and Statistics, Vol. 64, 1997, pp. 311-335.

Jensen, Robert, 'Agricultural Volatility and Investments in Children,' American Economic Association Papers and Proceedings, May 2000, pp. 399-404.

Lipton, Michael, 'Migration from Rural Areas of Poor Countries: The Impact on Rural Productivity and Income Distribution', World Development, Vol. 8, No. 1, January 1980, pp. 1-24.

Lucas, Robert E.B., and Oded Stark, 'Motivations to Remit: Evidence from Botswana,' Journal of Political Economy, Vol. 93, No. 5, 1985, pp. 901-918.

Massey, Douglas S., Raul Alarcon, Jorge Durand, and H. Gonzalez, Return to Aztlan: The Social Process of International Migration from Western Mexico. Berkeley: University of California Press, 1987.

Massey, Douglas S. and Emilio A. Parrado, 'International Migration and Business Formation in Mexico,' Social Science Quarterly, Vol. 79, No. 1, March 1998, pp. 1-19.

McCormick, Barry and Jackline Wahba, 'Overseas Work Experience, Savings and Entrepreneurship Amongst Return Migrants to LDCs,' Scottish Journal of Political Economy, Vol. 48, No. 2, May 2001, pp. 164-178.

Mesnard, Alice, 'Temporary Migration and Capital Market Imperfections,' Oxford Economic Papers, Vol. 56, 2004, pp. 242-262.

Miguel, Edward, 'Poverty and Witch Killing,' Review of Economic Studies, Vol. 72, No. 4, 2005, pp. 1153-1172.

Orozco, Manuel, 'Worker Remittances: An International Comparison,' working paper, InterAmerican Development Bank, February 2003.

Philippine Yearbook, Manila: National Statistics Office, 2001.

Poirine, Bernard, 'A Theory of Remittances as an Implicit Family Loan Arrangement,' World Development, Vol. 25, No. 4, 1997, pp. 589-611.

Radelet, Steven and Jeffrey Sachs, "The Onset of the East Asian Financial Crisis," NBER Working Paper 6680, August 1998.

Ratha, Dilip, "Workers' Remittances: An Important and Stable Source of External Development Finance," in Global Development Finance 2003: Striving for Stability in Development Finance. Washington, DC: International Monetary Fund, 2003, pp. 157-175. 
Reichert, J., 'The Migrant Syndrome: Seasonal US Wage Labor and Rural Development in Central Mexico,' Human Organization, Vol. 40, No. 1, pp. 56-66.

Rose, Eliana, 'Consumption Smoothing and Excess Female Mortality in Rural India,' Review of Economics and Statistics, Vol. 81, No. 1, 1999, pp. 41-49.

Rosenzweig, Mark and Oded Stark, 'Consumption Smoothing, Migration, and Marriage: Evidence from Rural India,' Journal of Political Economy, Vol. 97, No. 4, 1989, pp. 905-926.

Rosenzweig, Mark and Kenneth Wolpin, 'Credit Market Constraints, Consumption Smoothing and the Accumulation of Durable Production Assets in Low-Income Countries: Investments in Bullocks in India,' Journal of Political Economy 101, 1993, pp. 223-244.

Rosenzweig, Mark and Kenneth Wolpin, 'Natural 'Natural Experiments' in Economics,' Journal of Economic Literature, Vol. 38, December 2000, pp. 827-874.

Stark, Oded, The Migration of Labor. Oxford: Basil Blackwell, 1991.

Taylor, J. Edward and Philip L. Martin, 'Human Capital: Migration and Rural Population Change,' in Bruce L. Gardner and Gordon C. Rausser, eds. Handbook of Agricultural Economics, Volume 1A. Amsterdam: Elsevier Science, North-Holland, 2001, pp. 457-511.

Taylor, J. Edward, Scott Rozelle, and Alan de Brauw, 'Migration and Incomes in Source Communities: A New Economics of Migration Perspective from China,' Economic Development and Cultural Change, Vol. 52, 2003, pp. 75-101.

United Nations, International Migration Report 2002, UN Population Division, New York.

United States Bureau of the Census, International Data Base, Washington, D.C., 2002.

Woodruff, Christopher and Rene Zenteno, 'Remittances and Microenterprises in Mexico,' mimeo, University of California, San Diego and ITESM, 2003.

World Bank, World Development Indicators on CD-ROM 2004, Washington, D.C.

Yang, Dean, "Why Do Migrants Return to Poor Countries? Evidence from Philippine Migrants' Responses to Exchange Rate Shocks," Review of Economics and Statistics, forthcoming. 
Table 1 Locations of overseas workers from sample households

(June 1997)

$\underline{\text { Location }}$

Saudi Arabia

Hong Kong, China

Taiwan

Singapore

Japan

United States

Malaysia

Italy

Kuwait

United Arab Emirates

Greece

Korea, Rep.

Northern Mariana Islands

Canada

Brunei

United Kingdom

Qatar

Norway

Australia

Bahrain

Other

Total
Number of overseas workers \% of total

\author{
Exchange rate \\ shock \\ (June 1997- \\ Oct 1998)
}

$\begin{array}{ccc}521 & 28.4 \% & 0.52 \\ 210 & 11.5 \% & 0.52 \\ 148 & 8.1 \% & 0.26 \\ 124 & 6.8 \% & 0.29 \\ 116 & 6.3 \% & 0.32 \\ 116 & 6.3 \% & 0.52 \\ 65 & 3.5 \% & -0.01 \\ 52 & 2.8 \% & 0.38 \\ 51 & 2.8 \% & 0.50 \\ 49 & 2.7 \% & 0.52 \\ 44 & 2.4 \% & 0.30 \\ 36 & 2.0 \% & -0.04 \\ 30 & 1.6 \% & 0.52 \\ 29 & 1.6 \% & 0.42 \\ 22 & 1.2 \% & 0.30 \\ 15 & 0.8 \% & 0.55 \\ 15 & 0.8 \% & 0.52 \\ 14 & 0.8 \% & 0.35 \\ 14 & 0.8 \% & 0.24 \\ 13 & 0.7 \% & 0.52 \\ 148 & 8.1 \% & \\ 1,832 & 100.0 \% & \end{array}$

NOTES -- Data are from Oct 1997 Survey on Overseas Filipinos. "Other" includes 38 additional countries plus a category for "unspecified" (total 58 countries explicitly reported). Overseas workers in table are those in households included in sample for empirical analysis (see Data Appendix for details on sample definition). Exchange rate shock: Change in Philippine pesos per currency unit where overseas worker was located in Jun 1997. Change is average of 12 months leading to Oct 1998 minus average of 12 months leading to Jun 1997 , divided by the latter (e.g., $10 \%$ increase is 0.1 ). 


\section{Table 2 Characteristics of overseas workers from sample households}

\begin{tabular}{|c|c|c|c|c|c|}
\hline & Mean & Std. Dev. & 10th pctile & $\underline{\text { Median }}$ & 90th pctile \\
\hline Age & 34.49 & 9.00 & 24.00 & 33.00 & 47.00 \\
\hline Marital status is single (indicator) & 0.38 & & & & \\
\hline Gender is male (indicator) & 0.53 & & & & \\
\hline \multicolumn{6}{|l|}{ Occupation (indicators) } \\
\hline Production and related workers & 0.31 & & & & \\
\hline Domestic servants & 0.31 & & & & \\
\hline Ship's officers and crew & 0.12 & & & & \\
\hline Professional and technical workers & 0.11 & & & & \\
\hline Clerical and related workers & 0.04 & & & & \\
\hline Other services & 0.10 & & & & \\
\hline Other & 0.01 & & & & \\
\hline \multicolumn{6}{|l|}{ Highest education level (indicators) } \\
\hline Less than high school & 0.15 & & & & \\
\hline High school & 0.25 & & & & \\
\hline Some college & 0.31 & & & & \\
\hline College or more & 0.30 & & & & \\
\hline \multicolumn{6}{|l|}{ Position in household (indicators) } \\
\hline Male head of household & 0.28 & & & & \\
\hline Female head or spouse of head & 0.12 & & & & \\
\hline Daughter of head & 0.28 & & & & \\
\hline Son of head & 0.15 & & & & \\
\hline Other relation to head & 0.16 & & & & \\
\hline \multicolumn{6}{|l|}{ Months overseas as of Jun 1997 (indicators) } \\
\hline 0 -11 months & 0.30 & & & & \\
\hline $12-23$ months & 0.24 & & & & \\
\hline 24-35 months & 0.16 & & & & \\
\hline 36-47 months & 0.15 & & & & \\
\hline 48 months or more & 0.16 & & & & \\
\hline
\end{tabular}

Number of individuals:

1,832

NOTE -- Data source is October 1997 Survey on Overseas Filipinos, National Statistics Office of the Philippines. "Other" occupational category includes "administrative, executive, and managerial workers" and "agricultural workers". Overseas workers in table are those in households included in sample for empirical analysis (see Data Appendix for details on sample definition). 
Table 3 Initial characteristics of sample households

Num. of obs.: 1,646

Exchange rate shock (see below for definition)

\begin{tabular}{|c|c|c|c|c|}
\hline Mean & $\underline{\text { Std. Dev. }}$ & 10th pctile & Median & 90th pctile \\
\hline 0.41 & 0.16 & 0.26 & 0.52 & 0.52 \\
\hline 68,913 & 63,070 & 23,814 & 53,909 & 123,388 \\
\hline 94,272 & 92,826 & 28,093 & 70,906 & 175,000 \\
\hline 20,235 & 21,403 & 5,510 & 15,236 & 39,212 \\
\hline 36,194 & 46,836 & 0 & 26,000 & 87,500 \\
\hline
\end{tabular}

Household financial statistics (Jan-Jun 1997)

Total expenditures
Total income
Income per capita in household
Remittance receipts
Remittance receipts (as share of hh income)

Number of HH members working overseas in Jun 1997

HH size (including overseas members, Jul 1997)

1.11

0.31

0.00

0.37

0.85

Located in urban area

6.16

0.36

1

2.42

1

1

0.68

$\underline{\mathrm{HH}}$ position in national income per capita distribution, Jan- Jun 1997 (indicators)

Top quartile $\quad 0.51$

3rd quartile $\quad 0.28$

2nd quartile $\quad 0.14$

$\begin{array}{ll}\text { Bottom quartile } & 0.07\end{array}$

HH income sources (Jan-Jun 1997)

Wage and salary, as share of total $\quad 0.23$

Indicator: nonzero wage and salary income $\quad 0.53$

Entrepreneurial income, as share of total $\quad 0.17$

Indicator: nonzero entrepreneurial income $\quad 0.50$

Agricultural income, as share of total $\quad 0.10$

Indicator: nonzero agricultural income

0.50

Household head characteristics (Jul 1997):

Age

49.9

0.00

$0.07 \quad 0.68$

Highest education level (indicators)

$\begin{array}{llll}0.25 & 0.00 & 0.00 & 0.58\end{array}$

$\begin{array}{llll}0.21 & 0.00 & 0.00 & 0.42\end{array}$

Less than elementary $\quad 0.17$

Elementary $\quad 0.20$

Some high school $\quad 0.10$

High school $\quad 0.22$

Some college $\quad 0.16$

College or more $\quad 0.14$

$\begin{array}{cc}\text { Occupation (indicators) } & \\ \text { Agriculture } & 0.23\end{array}$

Professional job $\quad 0.08$

Clerical job $\quad 0.13$

Service job $\quad 0.05$

Production job $\quad 0.14$

Other $\quad 0.38$

Does not work $\quad 0.00$

Marital status is single (indicator) $\quad 0.03$

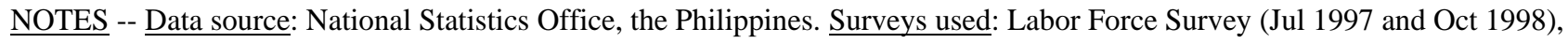
Survey on Overseas Filipinos (Oct 1997 and Oct 1998), 1997 Family Income and Expenditures Survey (for Jan-Jun 1997 income and expenditures), and 1998 Annual Poverty Indicators Survey (for Apr-Sep 1998 income and expenditures). Currency unit: Expenditure, income, and cash receipts from abroad are in Philippine pesos (26 per US\$ in Jan-Jun 1997). Definition of exchange rate shock: Change in Philippine pesos per currency unit where overseas worker was located in Jun 1997. Change is average of 12 months leading to Oct 1998 minus average of 12 months leading to Jun 1997, divided by the latter (e.g., 10\% increase is 0.1). If household has more than one overseas worker in Jun 1997, exchange rate shock variable is average change in exchange rate across household's overseas workers. (Exchange rate data are from Bloomberg L.P.) Sample definition: Households with a member working overseas in Jun 1996 (according to Oct 1997 Survey of Overseas Filipinos) and that also appear in 1998 Annual Poverty Indicators Survey, and excluding households with incomplete data (see Data Appendix for details). 
Table 4

Impact of migrant exchange rate shocks, 1997-1998

OLS regressions of change in outcome variable on exchange rate shock. Columns 1 and 2 report coefficients (standard errors) on exchange rate shock.

\begin{tabular}{|c|c|}
\hline & $\frac{\text { Mean }}{\text { (std.dev.) of }}$ \\
\hline Initial mean & change in \\
\hline
\end{tabular}

Panel A: Remittances, migrant returns

Remittance receipts

Migrant return rate (over 15 months)

Panel B: Income and consumption

Household income

Wage and salary income

Entrepreneurial income

Other sources of income (includes remittances)

Household consumption

\section{Panel C: Non-consumption disbursements}

Disbursements, potentially investment-related

Educational expenditures

Purchases of real property

Repayments of loans

Bank deposits

Other non-consumption disbursements

\section{Panel D: Durable good ownership}

Radio

Television

Living room set

Dining set

Refrigerator

Vehicle

Specification:

$$
\begin{aligned}
& \text { Region*Urban controls } \\
& \text { Controls for pre-crisis household and } \\
& \quad \text { migrant characteristics }
\end{aligned}
$$

Num. of obs. in all regressions:

$\begin{array}{cccc}0.395 & 0.151 & 0.175 & 0.238 \\ & (0.022) & (0.119) & (0.086)^{* * *} \\ & & & \\ \text { n.a. } & 0.136 & -0.155 & -0.125 \\ & (0.008) & (0.048)^{* * *} & (0.064)^{*}\end{array}$

1.000

0.251

0.258

(0.030)

(0.162)

0.26

$(0.126)^{* *}$

0.234

0.063

0.027

(0.044)

$-0.008$

$(0.049)$

0.166

0.023

0.041

0.029

(0.034)

(0.041)

$0.6 \quad 0.165$

0.189

0.239

(0.023)

(0.137)

1.000

$-0.063$

(0.068)

$-0.083$

$(0.074)$

Implied elasticity (coefficient in col. 2 divided by initial mean)

(0.012)

0.17

0.066

0.235

0.244

(0.130)*

1.37

(0.012)

(0.124)*

0.036

(0.013)*

$(0.016)^{* *}$

0.55

(0.002)

0.13

(0.101)

0.13

(0.100)

(0.006)

0.027

$(0.025)$

0.009

$(0.020)$

$(0.004)$

0.055

$(0.040)$

0.069

(0.044)

0.042

$-0.003$

(0.071)

$-0.003$

$(0.059)$

6.84

0.38

1.00

$-0.04$

* significant at $10 \%$; ** significant at $5 \%$; ** significant at $1 \%$ (NOTES continue on next page.) 


\section{Continuation of Table 4}

NOTES -- Each cell in regression columns 1-2 presents coefficient estimate on exchange rate shock in a separate OLS regression. Standard errors in parentheses, clustered by location country of household's eldest overseas worker. All dependent variables (except migrant return rate) are first-differenced variables. Number of overseas members is change between June 1997 and October 1998. For remittance variable, change is between Jan-Jun 1997 and Apr-Sep 1998 reporting periods, expressed as fraction of initial (Jan-Jun 1997) household income. Income changes are between Jan-Jun 1997 and Apr-Sep 1998 reporting periods, expressed as fractions of initial (Jan-Jun 1997) household income. Changes in consumption and disbursements are between Jan-Jun 1997 and Apr-Sep 1998 reporting periods, expressed as fractions of initial (Jan-Jun 1997) consumption.

"Other non-consumption disbursements" include installment payments on items purchased before 1997, loans provided to non-family members, and other payments. Durable goods variables are changes in indicator variables for ownership of given item between Jan 1998 and Oct 1998. See Table 3 for notes on sample definition and definition of exchange rate shock. Migrant return rate is number of migrant returns between July 1997 and September 1998, divided by number of household migrants in June 1997. Region*Urban controls are 16 indicators for regions within the Philippines and their interactions with an indicator for urban location. Householdlevel controls are as follows. Income variables as reported in Jan-Jun 1997: log of per capita household income; indicators for being in 2nd, 3rd, and top quartile of sample distribution of household per capita income.

Demographic and occupational variables as reported in July 1997: number of household members (including overseas members); five indicators for head's highest level of education completed (elementary, some high school, high school, some college, and college or more; less than elementary omitted); head's age; indicator for "head's marital status is single"; six indicators for head's occupation (professional, clerical, service, production, other, not working; agricultural omitted). Migrant controls are means of the following variables across HH's overseas workers away in June 1997: indicators for months away (12-23, 24-35, 36-47, 48 or more; 0-11 omitted); indicators for highest education level completed (high school, some college, college or more; less than high school omitted); occupation indicators (domestic servant, ship's officer or crew, professional, clerical, other service, other occupation; production omitted); relationship to HH head indicators (female head or spouse of head, daughter, son, other relation; male head omitted); indicator for single marital status; years of age. 
Table 5 Impact of migrant exchange rate shocks on schooling and labor supply of children aged 10-17, 1997-1998

Individual-level OLS regressions of change in outcome variable on exchange rate shock. Table reports coefficients (standard errors) on exchange rate shock.

$\underline{\text { Both females and males }}$

Regressions

\begin{tabular}{|c|c|c|c|}
\hline $\begin{array}{l}\frac{\text { Initial }}{\text { mean of }} \\
\text { outcome }\end{array}$ & $\frac{\frac{\text { Mean (std. }}{\underline{\text { dev.) of }}}}{\underline{\text { change in }}}$ & (1) & (2) \\
\hline 0.94 & $\begin{array}{l}-0.036 \\
(0.007)\end{array}$ & $\begin{array}{c}0.074 \\
(0.048)\end{array}$ & $\begin{array}{c}0.103 \\
(0.041)^{* *}\end{array}$ \\
\hline 1.10 & $\begin{array}{c}0.971 \\
(0.221)\end{array}$ & $\begin{array}{c}-2.194 \\
(1.072)^{* *}\end{array}$ & $\begin{array}{c}-2.215 \\
(0.905)^{* *}\end{array}$ \\
\hline 0.34 & $\begin{array}{c}0.655 \\
(0.131)\end{array}$ & $\begin{array}{c}-0.986 \\
(0.709)\end{array}$ & $\begin{array}{l}-0.225 \\
(0.683)\end{array}$ \\
\hline 0.10 & $\begin{array}{c}0.043 \\
(0.095)\end{array}$ & $\begin{array}{c}1.06 \\
(0.376)^{* * *}\end{array}$ & $\begin{array}{c}1.032 \\
(0.500)^{* *}\end{array}$ \\
\hline 0.66 & $\begin{array}{c}0.274 \\
(0.176)\end{array}$ & $\begin{array}{c}-2.268 \\
(0.639)^{* * *}\end{array}$ & $\begin{array}{c}-3.022 \\
(0.739)^{* * *}\end{array}$ \\
\hline
\end{tabular}

$\underline{\text { Females }}$

\begin{tabular}{|c|c|c|c|}
\hline \multirow[b]{2}{*}{$\underline{\underline{\text { Initial }}} \frac{\text { mean of }}{\text { outcome }}$} & \multicolumn{3}{|c|}{ Regressions } \\
\hline & $\frac{\frac{\text { Mean (std. }}{\underline{\text { dev.) of }}}}{\underline{\text { change in }}}$ & (3) & (4) \\
\hline 0.95 & $\begin{array}{l}-0.019 \\
(0.010)\end{array}$ & $\begin{array}{c}0.117 \\
(0.086)\end{array}$ & $\begin{array}{c}0.13 \\
(0.061)^{* *}\end{array}$ \\
\hline 0.64 & $\begin{array}{c}0.339 \\
(0.233)\end{array}$ & $\begin{array}{l}-2.753 \\
(2.044)\end{array}$ & $\begin{array}{c}-2.14 \\
(2.246)\end{array}$ \\
\hline 0.25 & $\begin{array}{c}0.143 \\
(0.154)\end{array}$ & $\begin{array}{l}-1.276 \\
(1.392)\end{array}$ & $\begin{array}{l}-0.547 \\
(2.023)\end{array}$ \\
\hline 0.02 & $\begin{array}{c}0.043 \\
(0.053)\end{array}$ & $\begin{array}{c}0.216 \\
(0.151)\end{array}$ & $\begin{array}{c}0.243 \\
(0.228)\end{array}$ \\
\hline 0.38 & $\begin{array}{c}0.152 \\
(0.123)\end{array}$ & $\begin{array}{c}-1.693 \\
(0.793)^{* *}\end{array}$ & $\begin{array}{c}-1.837 \\
(0.936)^{*}\end{array}$ \\
\hline
\end{tabular}

Males

\begin{tabular}{|c|c|c|c|}
\hline \multirow[b]{2}{*}{$\frac{\underline{\text { Initial }}}{\underline{\text { mean of }}}$} & \multicolumn{3}{|c|}{ Regressions } \\
\hline & 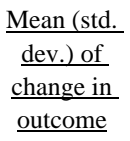 & (5) & (6) \\
\hline 0.93 & $\begin{array}{l}-0.053 \\
(0.013)\end{array}$ & $\begin{array}{c}0.022 \\
(0.050)\end{array}$ & $\begin{array}{c}0.068 \\
(0.061)\end{array}$ \\
\hline 1.53 & $\begin{array}{c}1.573 \\
(0.414)\end{array}$ & $\begin{array}{l}-1.448 \\
(1.710)\end{array}$ & $\begin{array}{c}-3.234 \\
(1.407)^{* *}\end{array}$ \\
\hline 0.43 & $\begin{array}{c}1.141 \\
(0.232)\end{array}$ & $\begin{array}{c}-0.52 \\
(0.978)\end{array}$ & $\begin{array}{l}-0.268 \\
(1.411)\end{array}$ \\
\hline 0.18 & $\begin{array}{c}0.043 \\
(0.158)\end{array}$ & $\begin{array}{c}1.858 \\
(0.639)^{* * *}\end{array}$ & $\begin{array}{c}1.976 \\
(1.100)^{*}\end{array}$ \\
\hline 0.93 & $\begin{array}{c}0.389 \\
(0.322)\end{array}$ & $\begin{array}{c}-2.786 \\
(1.296)^{* *}\end{array}$ & $\begin{array}{c}-4.942 \\
(1.523)^{* * *}\end{array}$ \\
\hline
\end{tabular}

Specification:

\author{
Region*Urban controls \\ Controls for pre-crisis individual, household and \\ migrant characteristics
}

Num. of obs. in all regs. in column:

$\begin{array}{cc}- & \mathrm{Y} \\ - & \mathrm{Y} \\ 1,188 & 1,188\end{array}$

$\begin{array}{cc}- & \mathrm{Y} \\ - & \mathrm{Y} \\ 579 & 579\end{array}$

$\begin{array}{ll}- & Y \\ - & Y \\ & \end{array}$

* significant at $10 \%$; ** significant at $5 \%$; *** significant at $1 \%$

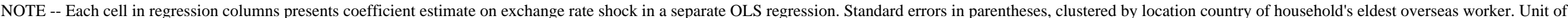

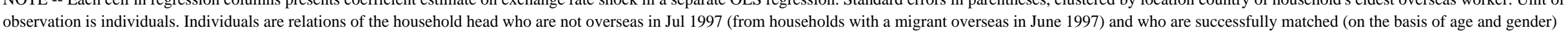

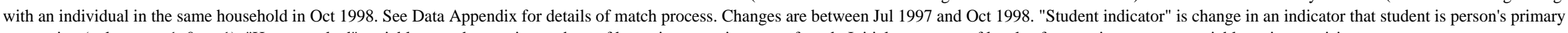
occupation (values are $-1,0$, or 1). "Hours worked" variables are changes in numbers of hours in respective type of work. Initial means are of levels of respective outcome variables prior to crisis.

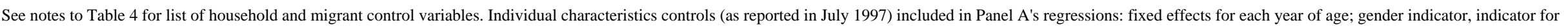

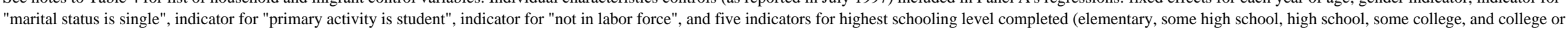
more). 
$\underline{\text { Table } 6}$ Impact of migrant exchange rate shocks on household labor supply by worker category, 1997-1998

OLS regressions of change in outcome variable on exchange rate shock. Table reports coefficients (standard errors) on exchange rate shock.

Outcomes: Change in...

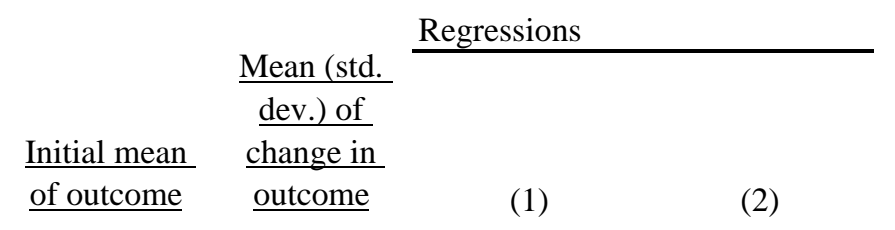

Total hours worked

72.6

$\begin{array}{cc}-0.68 & 9.276 \\ (1.199) & (9.934)\end{array}$

5.266

Hours worked:

For employer outside household

In self employment

As employer in own family-operated

As worker with pay in own family-operated

Specification:

Region*Urban controls

$\begin{array}{ll}- & \mathrm{Y} \\ - & \mathrm{Y}\end{array}$

migrant characteristics

1,646

Num. of obs. in all regressions:

* significant at $10 \%$; ** significant at $5 \%$; *** significant at $1 \%$

NOTE -- Each cell in regression columns 1-2 presents coefficient estimate on exchange rate shock in a separate OLS regression. Standard errors in parentheses, clustered by location country of household's eldest overseas worker. All dependent variables are changes in hours worked in past week by non-overseas household members, between Jul 1997 and Oct 1998 surveys. See Table 3 for notes on sample construction and variable definitions, and notes to Table 4 for list of control variables. 
Table 7 Impact of migrant exchange rate shocks on entrepreneurship, 1997-1998

OLS regressions of outcome variable on exchange rate shock. Table reports coefficients (standard errors) on exchange rate shock.

\section{Panel A: Entrepreneurial activities in general}

(Regression outcomes are changes in given variable.)

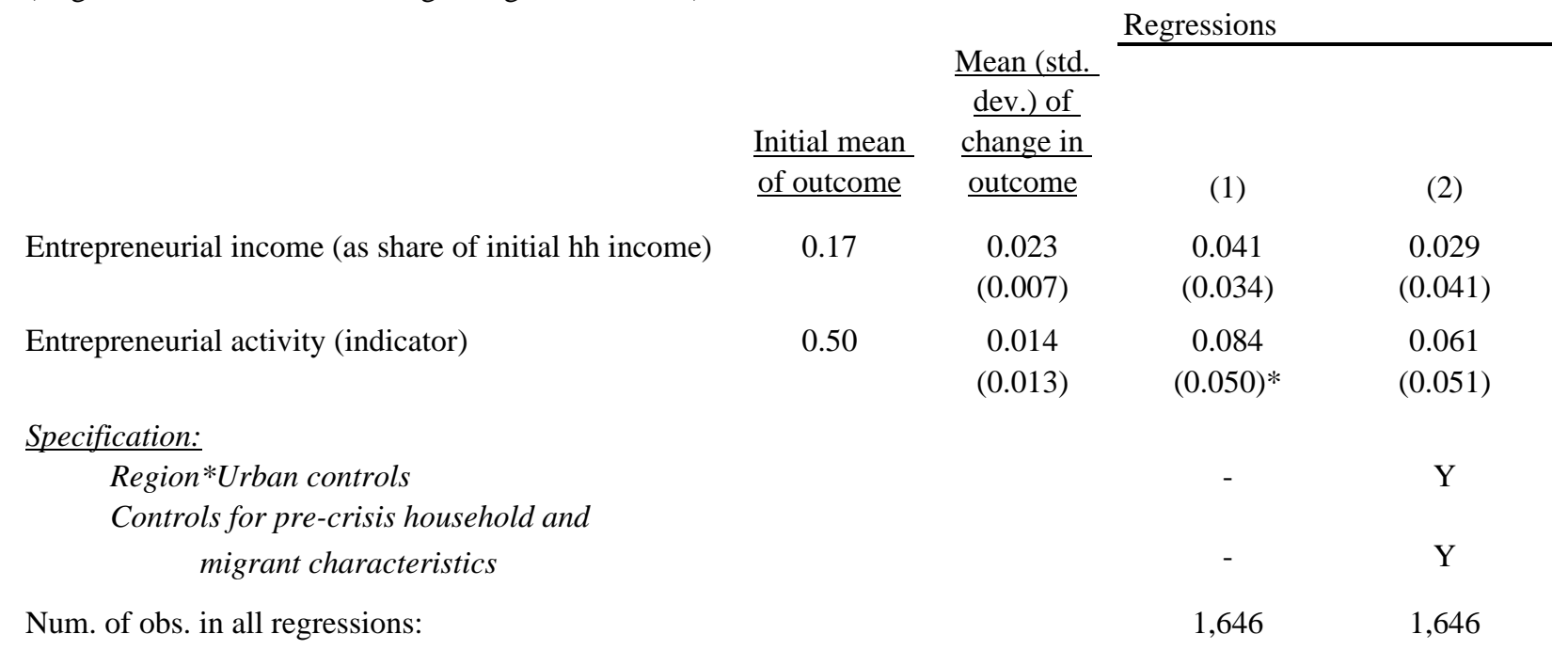

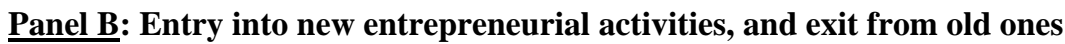

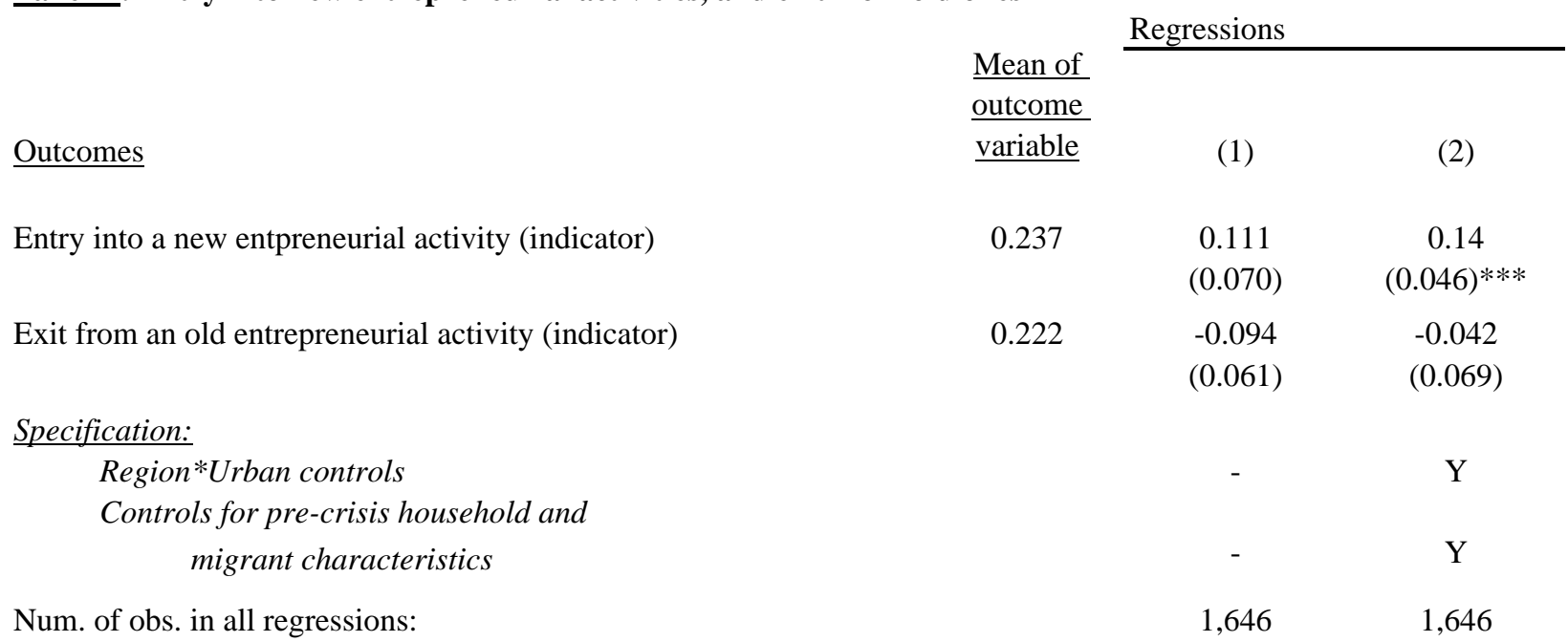

* significant at $10 \%$; ** significant at $5 \%$; *** significant at $1 \%$

NOTE -- Each cell in regression columns 1-2 presents coefficient estimate on exchange rate shock in a separate OLS regression. Standard errors in parentheses, clustered by location country of household's eldest overseas worker. Entrepreneurial income change is between Jan-Jun 1997 and Apr-Sep 1998 reporting periods, expressed as fraction of initial (Jan-Jun 1997) household income. Indicator for entrepreneurial activity equal to one if household reports engaging in any entrepreneurial activity. "Entry into a new entrepreneurial activity" indicator equal to one if household reported engaging in one or more specific types of activities in Apr-Sep 1998 that were not reported in Jan-Jun 1997, and zero otherwise. "Exit from an old entrepreneurial activity" indicator equal to one if household ceased engaging in one or more specific types of activities in Apr-Sep 1998 that were reported in Jan-Jun 1997, and zero otherwise. (See Appendix Table 2 for list of specific types of entrepreneurial activities.) See Table 3 for notes on sample construction and variable definitions, and notes to Table 4 for list of control variables. 
Table 8 Impact of migrant exchange rate shocks on specific types of entrepreneurial activities, 1997-1998

OLS regressions of outcome variable on exchange rate shock. Table reports coefficients (standard errors) on exchange rate shock.

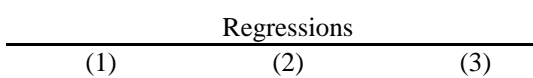

(1) (3)

Initial fraction of

hhs with nonzero Mean (std.dev.) income from this of net entry into source this activity

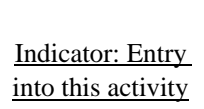

Crop farming and gardening

Wholesale and retail trade

Transportation and communication services

Livestock and poultry raising

Community and personal services

Manufacturing

Fishing

Forestry

Construction

Mining and quarrying

Activities not elsewhere classified

$\begin{array}{cc}0.219 & -0.016 \\ & (0.007) \\ 0.184 & 0.004 \\ & (0.006) \\ 0.082 & 0.007 \\ & (0.009) \\ 0.055 & 0.016 \\ & (0.007) \\ 0.043 & 0.01 \\ & (0.006) \\ 0.038 & -0.006 \\ & (0.004) \\ 0.015 & 0.004 \\ & (0.002) \\ 0.008 & -0.004 \\ & (0.002) \\ 0.002 & 0.004 \\ & (0.002) \\ 0.002 & 0.000 \\ & (0.001) \\ 0.008 & -0.002 \\ & (0.002) \\ & \end{array}$

$$
\text { (a) }
$$

0.018

$(0.019)$

0.003

(0.027)

0.045

$(0.025)^{*}$

0.028

$(0.040)$

$-0.005$

$(0.020)$

0.046

$(0.016)^{* * *}$

0.008

(0.009)

0.006

$(0.004)^{*}$

$-0.003$

(0.008)

$-0.003$

$(0.002)$

0.002

(0.010)
Indicator: Exit

activity

0.01

$(0.026)$

$-0.014$

$(0.054)$

$-0.031$

$(0.025)$

$-0.049$

$(0.030)$

0.017

$(0.020)$

$-0.013$

$(0.019)$

0.014

$(0.005)^{* * *}$

0.001

$(0.006)$

0.005

(0.003)*

0.001

$(0.001)$

0.006

(0.008) $\frac{\text { Net entry into }}{\text { this activity }}$

(a) - (b)

0.007

(0.036)

0.017

(0.070)

0.076

$(0.031)^{* *}$

0.077

(0.058)

$-0.022$

(0.024)

0.058

$(0.025)^{* *}$

$-0.006$

(0.010)

0.005

$(0.008)$

$-0.008$

(0.008)

$-0.004$

(0.003)

$-0.004$

(0.012)
Mean (std.dev.) Change in

nitial income change in income entrepreneurial from this source from this source income (as share (as share of hh (as share of hh of initial hh income) income) income)

$\begin{array}{ccc}0.066 & -0.01 & -0.017 \\ & (0.003) & (0.017) \\ 0.047 & 0.012 & -0.044 \\ & (0.004) & (0.028) \\ 0.019 & 0.011 & 0.055 \\ & (0.004) & (0.022)^{* *} \\ 0.006 & 0.002 & 0.014 \\ & (0.001) & (0.010) \\ 0.011 & 0.004 & -0.008 \\ & (0.002) & (0.011) \\ 0.006 & 0.000 & 0.016 \\ & (0.002) & (0.008)^{* *} \\ 0.007 & -0.001 & 0.009 \\ & (0.001) & (0.007) \\ 0.000 & 0.001 & 0.001 \\ & (0.001) & (0.003) \\ 0.001 & 0.001 & -0.003 \\ & (0.001) & (0.003) \\ 0.000 & 0.000 & -0.001 \\ & (0.000) & (0.001) \\ 0.002 & 0.000 & 0.001 \\ & (0.000) & (0.002)\end{array}$

Specification:

$$
\begin{aligned}
& \text { Region*Urban controls } \\
& \text { Controls for pre-crisis household and } \\
& \quad \text { migrant characteristics }
\end{aligned}
$$

Num. of obs. in all regressions in column:

$\begin{array}{ccc}\mathrm{Y} & \mathrm{Y} & \mathrm{Y} \\ \mathrm{Y} & \mathrm{Y} & \mathrm{Y} \\ 1,646 & 1,646 & 1,646\end{array}$

Y

1,646

* significant at $10 \%$; ** significant at $5 \%$; *** significant at $1 \%$

NOTE -- Each cell in regression columns 1-4 presents coefficient estimate on exchange rate shock in a separate OLS regression. Standard errors in parentheses, clustered by location country of household's eldest overseas worker. Outcome in regression column 1 (entry indicator) equal to 1 if household reported no income from the given activity prior to the crisis, but nonzero income after the crisis (and 0 otherwise). Outcome in regression column 2 (exit indicator) is equal to 1 if household reported nonzero income prior to the crisis but zero income after the crisis (and 0 otherwise). Outcome in column 3 (net entry) is column 1's outcome minus column 2's outcome. Outcome in regression column 4 is change in entrepreneurial income from given activity

between Jan-Jun 1997 and Apr-Sep 1998 reporting periods, expressed as fraction of initial (Jan-Jun 1997) household income. All regressions include control variables for household and migrant pre-crisis characteristics (listed in notes to Table 4). See Table 3 for notes on sample construction and variable definitions. 


\section{Table 9: Impact of migrant exchange rate shocks, 1997-1998 (additional specifications)}

OLS regressions of change in outcome variable on exchange rate shock, including controls for migrant return rate, migrant job loss, and real economic conditions overseas.

Dependent variables: Change in...

\begin{tabular}{|c|c|c|c|c|c|c|c|c|c|c|c|c|}
\hline \multirow{3}{*}{$\begin{array}{l}\text { Independent variables: } \\
\text { Exchange rate shock }\end{array}$} & \multicolumn{12}{|c|}{ Dependent variables: Change in... } \\
\hline & \multicolumn{2}{|c|}{$\underline{\text { Remittance receipts }}$} & \multicolumn{2}{|c|}{$\begin{array}{l}\text { Entry into a new } \\
\text { entrepreneurial activity }\end{array}$} & \multicolumn{2}{|c|}{$\begin{array}{l}\frac{\text { Net entry into }}{\text { "transportation and }} \\
\frac{\text { communication }}{\text { services" }} \\
\text { entrepreneurship }\end{array}$} & \multicolumn{2}{|c|}{$\begin{array}{l}\frac{\text { Net entry into }}{\text { "manufacturing" }} \\
\text { entrepreneurship }\end{array}$} & \multicolumn{2}{|c|}{$\frac{\text { Change in student status }}{\text { (children aged 10-17) }}$} & \multicolumn{2}{|c|}{$\frac{\text { Change in hours worked }}{\text { (children aged 10-17) }}$} \\
\hline & $\begin{array}{c}0.234 \\
(0.088)^{* *}\end{array}$ & $\begin{array}{c}0.296 \\
(0.122)^{* *}\end{array}$ & $\begin{array}{c}0.139 \\
(0.046)^{* * *}\end{array}$ & $\begin{array}{c}0.128 \\
(0.065)^{*}\end{array}$ & $\begin{array}{c}0.087 \\
(0.032)^{* * *}\end{array}$ & $\begin{array}{c}0.099 \\
(0.028)^{* * *}\end{array}$ & $\begin{array}{c}0.053 \\
(0.025)^{* *}\end{array}$ & $\begin{array}{c}0.059 \\
(0.024)^{* *}\end{array}$ & $\begin{array}{c}0.091 \\
(0.037)^{* *}\end{array}$ & $\begin{array}{c}0.093 \\
(0.033)^{* * *}\end{array}$ & $\begin{array}{c}-2.104 \\
(1.007)^{* *}\end{array}$ & $\begin{array}{c}-2.199 \\
(1.057)^{* *}\end{array}$ \\
\hline $\begin{array}{r}\text { Migrant return rate } \\
\text { in household }\end{array}$ & & $\begin{array}{c}0.275 \\
(0.089)^{* * *}\end{array}$ & & $\begin{array}{c}0.018 \\
(0.034)\end{array}$ & & $\begin{array}{l}-0.017 \\
(0.013)\end{array}$ & & $\begin{array}{l}-0.006 \\
(0.018)\end{array}$ & & $\begin{array}{c}0.038 \\
(0.016)^{* *}\end{array}$ & & $\begin{array}{c}-1.426 \\
(0.371)^{* * *}\end{array}$ \\
\hline $\begin{array}{l}\text { Migrant job loss } \\
\text { (indicator) }\end{array}$ & & $\begin{array}{c}-0.197 \\
(0.078)^{* *}\end{array}$ & & $\begin{array}{c}0.05 \\
(0.048)\end{array}$ & & $\begin{array}{c}0.009 \\
(0.035)\end{array}$ & & $\begin{array}{c}0.016 \\
(0.014)\end{array}$ & & $\begin{array}{c}0.028 \\
(0.022)\end{array}$ & & $\begin{array}{l}0.756 \\
(0.951)\end{array}$ \\
\hline $\begin{array}{l}\text { Change in } \ln \text { (gross } \\
\text { domestic product) }\end{array}$ & & $\begin{array}{c}-0.39 \\
(0.647)\end{array}$ & & $\begin{array}{c}0.187 \\
(0.398)\end{array}$ & & $\begin{array}{c}-0.15 \\
(0.152)\end{array}$ & & $\begin{array}{l}-0.067 \\
(0.100)\end{array}$ & & $\begin{array}{c}0.13 \\
(0.265)\end{array}$ & & $\begin{array}{l}-2.211 \\
(6.093)\end{array}$ \\
\hline $\begin{array}{l}\text { R-squared } \\
\text { Num. of obs.: }\end{array}$ & $\begin{array}{c}0.1 \\
1,580\end{array}$ & $\begin{array}{c}0.12 \\
1,580\end{array}$ & $\begin{array}{c}0.07 \\
1,580\end{array}$ & $\begin{array}{c}0.07 \\
1,580\end{array}$ & $\begin{array}{c}0.04 \\
1,580\end{array}$ & $\begin{array}{c}0.04 \\
1,580\end{array}$ & $\begin{array}{c}0.05 \\
1,580\end{array}$ & $\begin{array}{c}0.06 \\
1,580\end{array}$ & $\begin{array}{c}0.27 \\
1,119\end{array}$ & $\begin{array}{c}0.27 \\
1,119\end{array}$ & $\begin{array}{c}0.16 \\
1,119\end{array}$ & $\begin{array}{c}0.16 \\
1,119\end{array}$ \\
\hline
\end{tabular}

* significant at $10 \%$; ** significant at $5 \%$; *** significant at $1 \%$

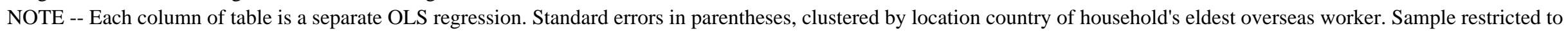

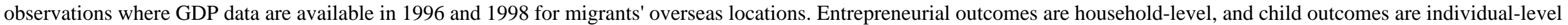

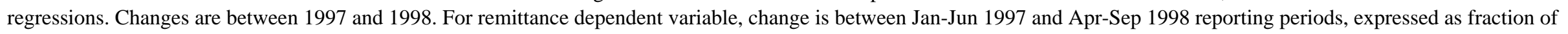
initial (Jan-Jun 1997) household income.

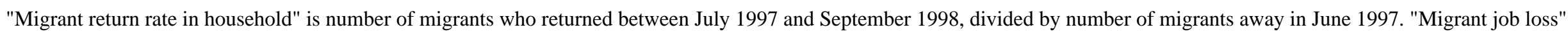

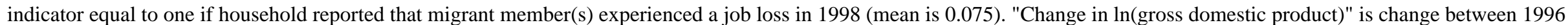

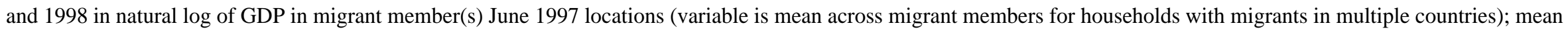

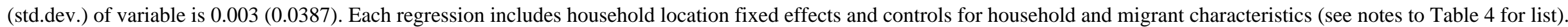
Regressions for child outcomes include controls for individual-level control variables (see notes to Table 5 for list). 


\begin{tabular}{cc} 
& Num. of observations \\
\cline { 2 - 2 } R-squared \\
Household head's highest education level \\
(indicators, less than elementary excluded) \\
Elementary & 0.022 \\
& $(0.014)$ \\
Some high school & 0.024 \\
& $(0.021)$ \\
High school & 0.042 \\
& $(0.018)^{* *}$ \\
Some college & 0.048 \\
& $(0.031)$ \\
College or more & 0.053 \\
& $(0.036)$
\end{tabular}

F-stat: joint signif of these vars.: $\quad 2.589$
Household per capita income percentile

(indicators, lowest quartile excluded) 25th-50th

0.032

50th-75th

Above 75th

0.008

0.001

$(0.032)$

F-stat: joint signif of these vars.: $\quad 3.532$ P-value: $\quad 0.021$

1,646

0.09

\begin{tabular}{cc}
\multicolumn{2}{l}{ Household head's occupation } \\
(indicators, agriculture excluded) \\
Professional & 0.004 \\
& $(0.013)$ \\
Clerical & -0.001 \\
& $(0.016)$ \\
Service & -0.014 \\
& $(0.025)$ \\
Production & -0.012 \\
& $(0.013)$ \\
Other & 0.003 \\
& $(0.009)$ \\
Not working & 0.067 \\
& $(0.047)$
\end{tabular}

Household size

$-0.005$

$(0.003)^{*}$

F-stat: joint signif of these vars.: $\quad 1.033$

P-value: $\quad 0.414$

Household location indicators

(16 region indicators interacted with urban location indicator)

F-stat: joint signif of these vars.: $\quad 14.284$

$$
\text { P-value: } \quad 0.000
$$

Overseas workers' months away

(fraction of HH overseas workers in each category, less than 12 months excluded)

12-23 months

0.013

24-35 months

(0.008)

0.036

36-47 months

$(0.010)^{* * *}$

0.041

48 months or more

$(0.015)^{* * *}$

0.043

Overseas workers' education

Overseas workers' occupation

Overseas workers' position in household

(fraction of HH overseas workers in each category, (fraction of HH overseas workers in each category, (fraction of HH overseas workers in each cat less than high school excluded)

High school

$-0.038$

$(0.022)$

College or more $\quad-0.021$

$(0.022)$

$(0.019)^{* *}$

F-stat: joint signif of these vars.: $\quad 2.658$

P-value: $\quad 0.057$

F-stat: joint signif of these vars.: $\quad 4.128$

$$
\text { P-value: } \quad 0.005
$$

* significant at $10 \%$; ** significant at $5 \%$; ** significant at $1 \%$

production worker excluded)

Domestic servant $\quad 0.039$

$\begin{array}{ll} & (0.046) \\ \text { Ship's officer or crew } \quad-0.057\end{array}$

-0.057
$(0.050)$

Professional

$-0.005$

Clerical

$(0.043)$

0.05

(0.044)

Other service

0.031

$(0.029)$

Other occupation

$(0.044)$

male household head excluded)

Female head or $\quad-0.027$

spouse of head $\quad(0.039)$

Daughter of head

$-0.012$

Son of head

$-0.009$

Other relation

$-0.001$

(0.029)

F-stat: joint signif of these vars.: $\quad 0.340$

P-value: $\quad 0.850$

F-stat: joint signif of these vars.: $\quad 3.284$

P-value: 0.008

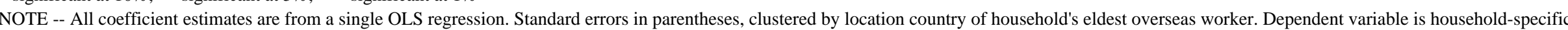

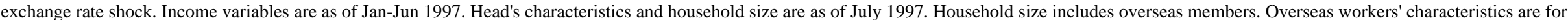
those away in June 1997 (reported in Oct 1997). Coefficients on household location indicators not reported. See Table 3 for definition of exchange rate shock and definition of sample households. 


\section{Appendix Table 2: Descriptions of specific types of entrepreneurial activity}

$\underline{\text { Type of entrepreneurial activity }}$

\section{Crop farming and gardening}

Wholesale and retail trade

Transportation and communication services

Livestock and poultry raising

Community and personal services

Manufacturing

Fishing

Forestry

Construction

Mining and quarrying

Activities not elsewhere classified

\section{Description/examples given in survey}

Growing of palay [rice], corn, roots and tubers, vegetables, fruits, nuts, orchids, ornamental plants, etc.

Includes market vending, sidewalk vending, and peddling.

Such as operation of jeepneys [a type of small bus] or taxis, storage and warehousing activities, messenger services, etc.

Such as raising of carabaos [water buffaloes], cattle, hogs, horses, chicken, ducks, etc. and the production of fresh milk, eggs, etc.

Such as medical and dental practice, practice of trade, operation of schools, restaurants and hotels, etc.

Such as mat weaving, tailoring, dressmaking, bagoong [fermented shrimp paste] making, fish drying, etc.

Such as capture fishing (with a boat of three tons or less); gathering fry, shells, seaweeds, etc.; and culturing fish, oyster, mussel, etc.

Cultivation or collection of forest products.

Includes repair of a house, building or any structure.

Such as mineral extraction like salt making, gold mining, gravel, sand, and stone quarrying, etc.

Including electricity, gas and water; financing, insurance, real estate and business service.

Note: Examples are as given in administering the Family Income and Expenditure Survey. 


\section{Appendix Table 3: Income, expenditures, and bank deposits in households with various types of entrepreneurial activities (Jan-Jun 1997) \\ OLS regressions}

Dependent variables: $\quad \frac{\text { Total household }}{\underline{\text { income (pesos) }}} \quad \frac{\text { Total household }}{\frac{\text { consumption }}{\text { (pesos) }}} \quad \frac{\text { Bank deposits }}{\text { (pesos) }}$

Fraction of households with given type of entrepreneurship

Constant (mean for hhs without entrepreneurship)

$\begin{array}{cc}61,739 & 53,320 \\ (665)^{* * *} & (464)^{* * *} \\ -27,367 & -22,641 \\ (1,047)^{* * *} & (731)^{* * *}\end{array}$

6,077

$(830)^{* * *}$

$(1,190) * * *$

18,156

$(1,430)^{* * *}$

$(2,049) * * *$

2,120

$(1,740)$

1,030

$(1,214)$

24,344

$(2,297) * * *$

13,937

$(2,215) * * *$

$-20,973$

$(2,129) * * *$

Forestry

$-18,353$

$(4,323) * * *$

Construction

Mining and quarrying

53,118

$(6,215) * * *$

7,211

$(9,168)$

15,460

$(1,603) * * *$

7,652

$(1,546)^{* * *}$

$-18,035$

$(1,485) * * *$

$-12,983$

$(3,016) * * *$

17,593

$(4,336) * * *$

3,899

$(6,396)$

31,137

$(3,534)^{* * *}$

$(5,065) * * *$

0.06

27,857
1,962

(386)***

$-758$

(608)

0.297

955

(691)

1,919

$(1,190)$

$-36$

(1,010)

6,267

$(1,334) * * *$

3,270

$(1,286)^{* *}$

0.187

0.053

0.079

0.042

0.045

$-1,227$

$(1,236)$

$-1,648$

$(2,510)$

19,478

$(3,608) * * *$

3,760

(5,322)

0.049

0.012

0.006

0.003

9,973

$(2,941)^{* * *}$

0.008
R-squared

Num. of obs.

\begin{abstract}
0.06
\end{abstract}
27,857
0

27,857

* significant at $10 \%$;* significant at $5 \%$; *** significant at $1 \%$

NOTE -- Each column of table is a separate OLS regression. Standard errors in parentheses. Sample is all households included in July 1997 Family Income and Expenditure Survey. Income and consumption variables are over Jan-Jun 1997. Bank deposits are as of July 1997. Independent variables (aside from constant) are indicator variables for whether household is engaged an a given type of entrepreneurial activity. Households can be engaged in more than one. Constant term represents mean of dependent variable for households without any entrepreneurial activities. 
Appendix Table 4 Impact of migrant shocks on attrition from household and individual panels, Jul 1997- Oct 1998

(Coefficients on exchange rate shock in OLS regression)

\section{Panel A: Households}

\begin{tabular}{|c|c|c|}
\hline & $\underline{\text { Mean of }}$ & $\frac{\text { Coef. on }}{\text { shock }}$ \\
\hline Outcome: attrition indicator & 0.056 & $\begin{array}{c}0.008 \\
(0.032)\end{array}$ \\
\hline
\end{tabular}

Number of obs.

1,743

Panel B: Individual males, aged 10-17

$\underline{\underline{\text { Mean of }}} \quad \frac{\text { Coef. on }}{\underline{\text { shock }}}$

Outcome: attrition indicator $\quad 0.238 \quad-0.091$

$(0.102)$

Number of obs.

800

Panel C: Individual females, aged 10-17

$\underline{\underline{\text { Mean of }}} \quad \underline{\text { Coef. on }}$

Outcome: attrition indicator $\quad 0.23 \quad 0.018$

(0.111)

Number of obs.

752

* significant at $10 \%$;** significant at $5 \%$; *** significant at $1 \%$

NOTE -- Each cell of table presents coefficient estimate on exchange rate shock in a separate OLS regression. Standard errors in parentheses, clustered by location country of household's eldest overseas worker. Unit of observation is the household in Part A, and the individual in Parts B and C. Individuals are those observed in Jul 1997 (from households with a migrant overseas in June 1997). For households, attrition indicator equal to 1 if household was excluded from sample because it changed dwellings between July 1997 and October 1998, or had missing data on outcome variables in October 1998. For individuals, attrition indicator equal to 1 if individual is not successfully matched (on the basis of age and gender) with an individual in the same household in Oct 1998, and 0 otherwise (see Data Appendix for details of match process).

Each regression includes household location fixed effects and controls for household and overseas worker characteristics. Individual-level regressions also include control variables for the following individual characteristics (as reported in July 1997): gender indicator, indicator for single marital status, indicator for "primary activity is student", indicator for "not in labor force", and five indicators for highest schooling level completed (elementary, some high school, high school, some college, and college or more). See notes to Table 4 for list of household and migrant control variables. 


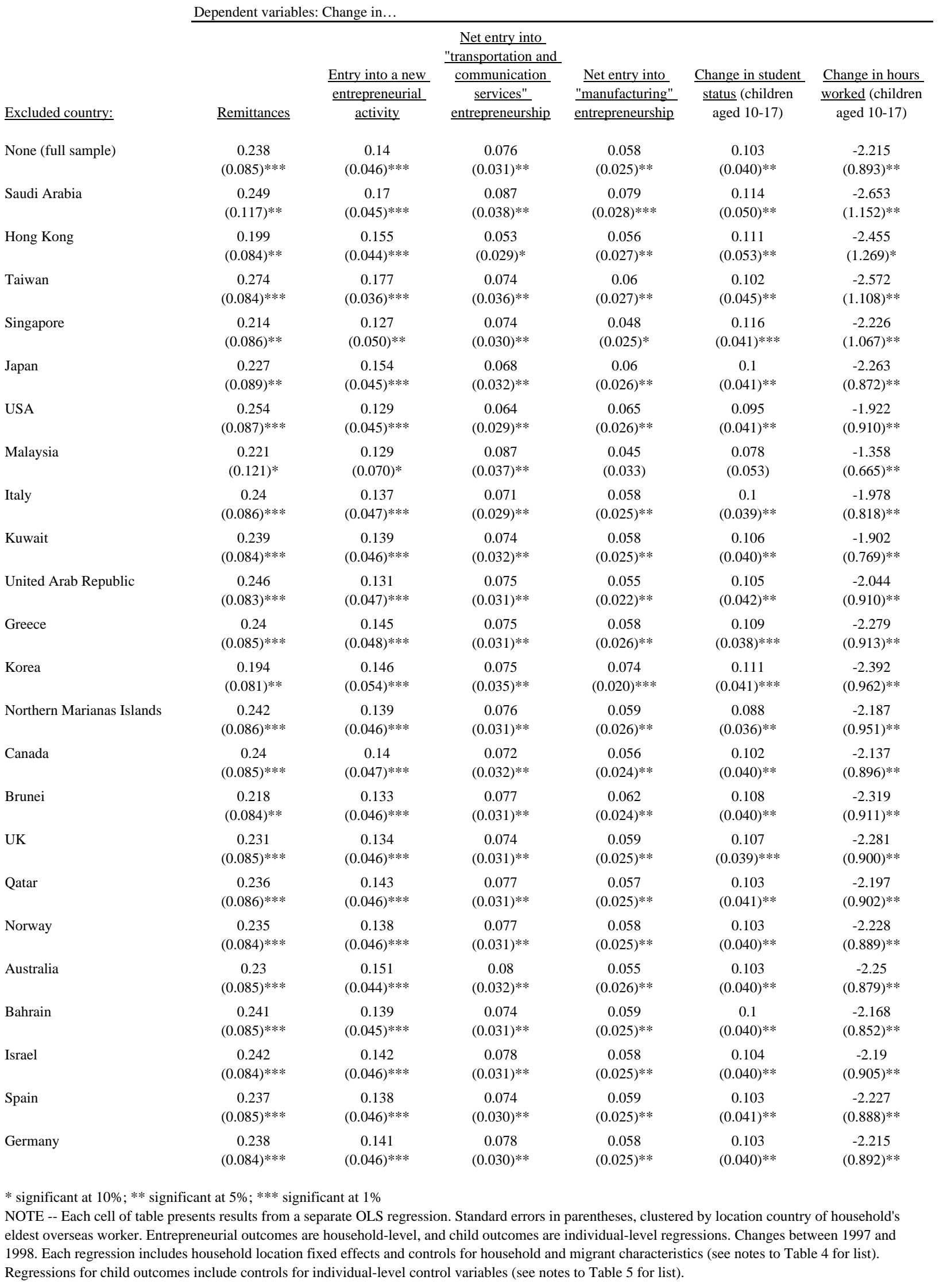




\section{Appendix Table 6: Impact of future migrant exchange rate shocks on household outcomes, 1996-1997}

(False experiment: dependent variable is from 1996-1997, exchange rate shock is from 1997-1998)

OLS regressions of change in outcome variable on exchange rate shock. Table reports coefficients (standard errors) on exchange rate shock.

Outcomes: Change in...

Remittance receipts

Total hours worked

Hours worked:

For employer outside household

In self employment

As employer in own family-operated farm or business

As worker with pay in own family-operated farm or business

As worker without pay in own family-operated farm or business

Specification:

Region*Urban controls

Controls for pre-crisis household and migrant characteristics

Num. of obs. in all regressions:

Regressions

(1)

$-0.261$

(0.216)

$-4.639$

(22.463)

$-7.502$

(10.834)

4.076

(12.216)

$-5.716$

(3.073)*

$-3.598$

(3.071)

8.102

(9.403)
(2)

$-0.26$

(0.228)

$-14.19$

(17.420)

$-14.376$

(12.321)

1.683

(9.815)

$-4.374$

$-3.354$

6.231

\section{Y}

Y

* significant at $10 \%$; ** significant at $5 \%$; *** significant at $1 \%$

NOTE -- Each cell in regression columns 1-2 presents coefficient estimate on future (Jul 1997 - Oct 1998) exchange rate shock in a separate OLS regression. Standard errors in parentheses, clustered by location country of household's eldest overseas worker. For remittance variable, change is between October 1996 and October 1997 (from Survey on Overseas Filipinos), expressed as fraction of Jan-Jun 1997 household income (from Family Income and Expenditure Survey). Hours worked variables are changes in hours worked in past week by non-overseas household members, between Jul 1996 and Jul 1997 (from Labor Force Survey).

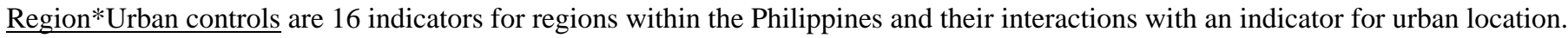
Household-level controls are as follows. Demographic and occupational variables as reported in July 1996: number of household members (including overseas members); five indicators for head's highest level of education completed (elementary, some high school, high school, some college, and college or more; less than elementary omitted); head's age; indicator for "head's marital status is single"; six indicators for head's occupation (professional, clerical, service, production, other, not working; agricultural omitted).

Migrant controls are means of the following variables across HH's overseas workers away in June 1997: indicators for months away (1223, 24-35, 36-47, 48 or more; 0-11 omitted); indicators for highest education level completed (high school, some college, college or more; less than high school omitted); occupation indicators (domestic servant, ship's officer or crew, professional, clerical, other service, other occupation; production omitted); relationship to HH head indicators (female head or spouse of head, daughter, son, other relation; male head omitted); indicator for single marital status; years of age. 
Figure 1: Impact of migrant exchange rate shocks on Philippine household remittance receipts (1997-1998)

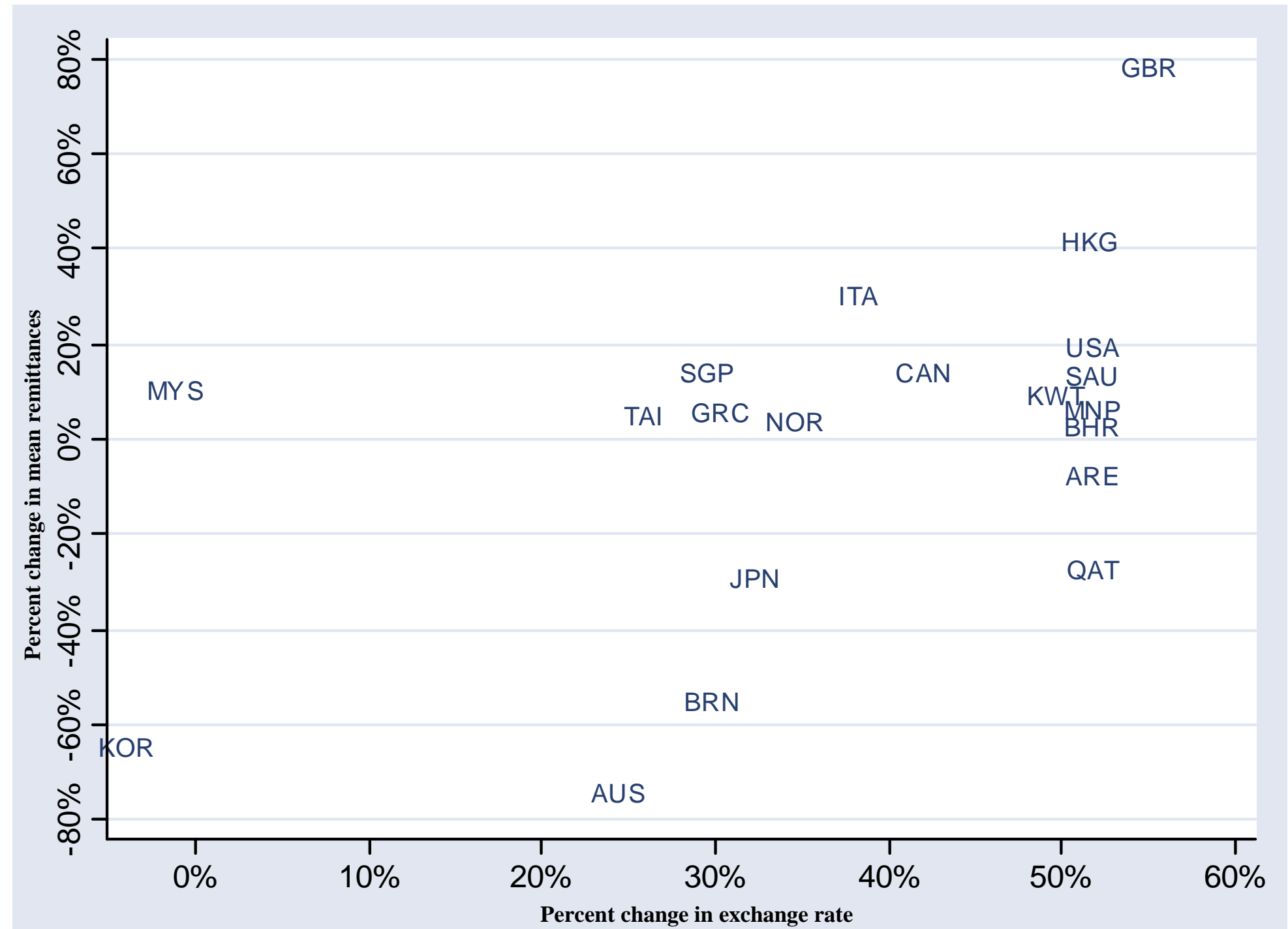

NOTES-Exchange rates are in Philippine pesos per unit of foreign currency. Percent change in exchange rate is mean exchange rate from Oct 1997 to Sep 1998 minus mean exchange rate from July 1996 to June 1997, divided by the latter. Mean remittances are calculated among all households with a single migrant in given overseas location. Percent change in mean remittances is between Jan - Jun 1997 and Apr-Sep 1998 reporting periods. Datapoints are the top 20 locations of Philippine overseas workers (as listed in Table 1). 
Figure 2: Exchange Rates in Selected Locations of Overseas Filipinos, July 1996 to October 1998

(Philippine pesos per unit of foreign currency, normalized to 1 in July 1996)

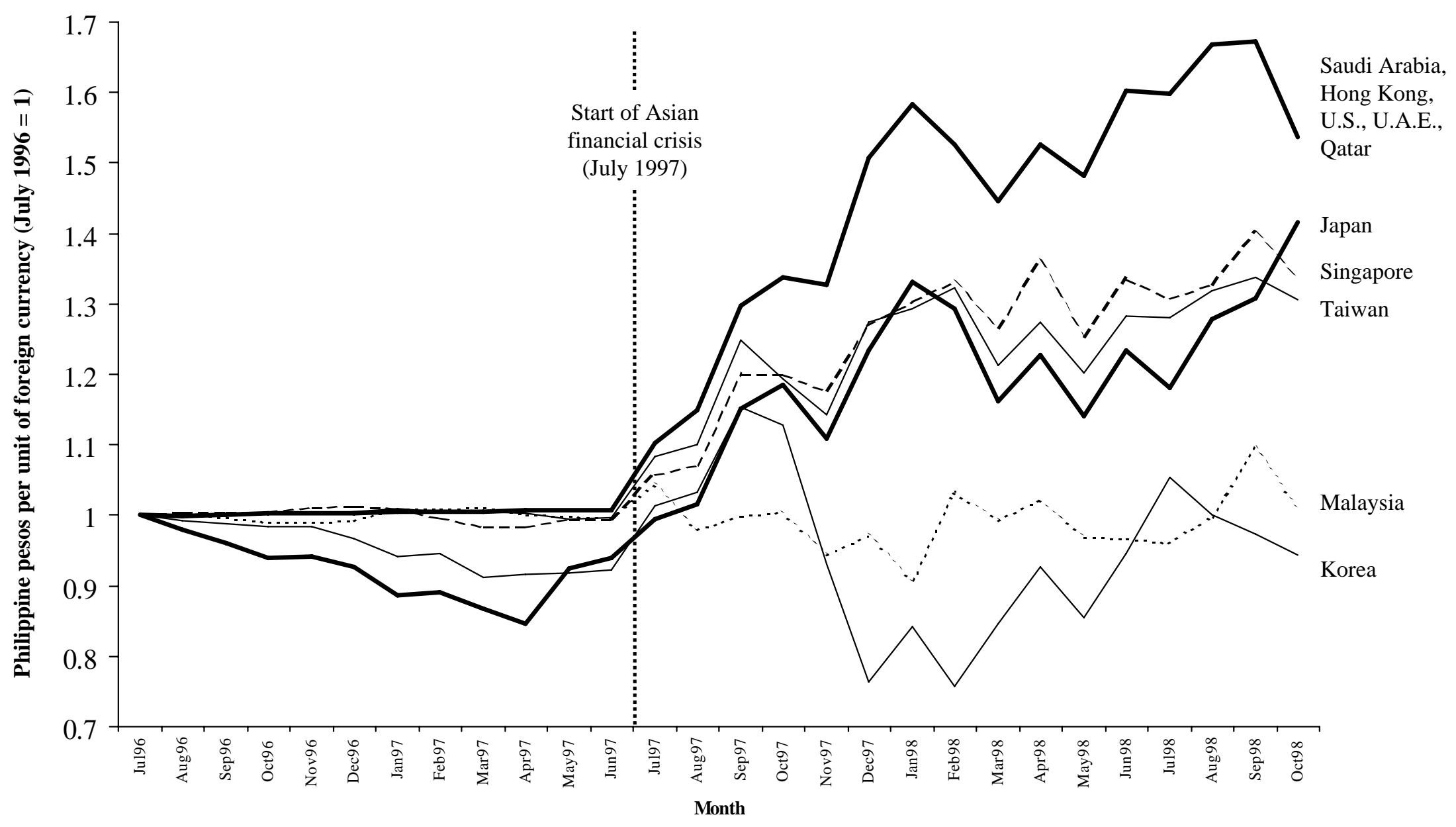

NOTES-- Exchange rates are as of last day of each month. Data source is Bloomberg L.P. 